\title{
A Review of Energy Consumption in the Acquisition of Bio-Feedstock for Microalgae Biofuel Production
}

\author{
Minghao Chen ${ }^{1,2,3} \mathbb{D}$, Yixuan Chen ${ }^{2,4}$ and Qingtao Zhang $1,2,3, * \mathbb{D}$ \\ 1 School of Civil Engineering, Zhuhai Campus, Sun Yat-sen University, Tangjiawan, Zhuhai 519082, China; \\ chenmh66@mail2.sysu.edu.cn \\ 2 Guangdong Provincial Key Laboratory for Marine Civil Engineering, Zhuhai Campus, \\ Sun Yat-sen University, Tangjiawan, Zhuhai 519082, China; chenyx227@mail2.sysu.edu.cn \\ 3 Guangdong Engineering Technology Research Center of Water Security Regulation and Control for Southern \\ China, Sun Yat-sen University, Guangzhou 510275, China \\ 4 School of Geography and Planning, Sun Yat-sen University, Guangzhou 510275, China \\ * Correspondence: zhangqt6@mail.sysu.edu.cn; Tel.: +86-180-2870-3301
}

Citation: Chen, M.; Chen, Y.; Zhang, Q. A Review of Energy Consumption in the Acquisition of Bio-Feedstock for Microalgae Biofuel Production. Sustainability 2021, 13, 8873. https:// doi.org/10.3390/su13168873

Academic Editor:

Alberto-Jesus Perea-Moreno

Received: 28 June 2021

Accepted: 29 July 2021

Published: 9 August 2021

Publisher's Note: MDPI stays neutral with regard to jurisdictional claims in published maps and institutional affiliations.

Copyright: (c) 2021 by the authors. Licensee MDPI, Basel, Switzerland. This article is an open access article distributed under the terms and conditions of the Creative Commons Attribution (CC BY) license (https:// creativecommons.org/licenses/by/ $4.0 /)$.

\begin{abstract}
Microalgae biofuel is expected to be an ideal alternative to fossil fuels to mitigate the effects of climate change and the energy crisis. However, the production process of microalgae biofuel is sometimes considered to be energy intensive and uneconomical, which limits its large-scale production. Several cultivation systems are used to acquire feedstock for microalgal biofuels production. The energy consumption of different cultivation systems is different, and the concentration of culture medium (microalgae cells contained in the unit volume of medium) and other properties of microalgae vary with the culture methods, which affects the energy consumption of subsequent processes. This review compared the energy consumption of different cultivation systems, including the open pond system, four types of closed photobioreactor (PBR) systems, and the hybrid cultivation system, and the energy consumption of the subsequent harvesting process. The biomass concentration and areal biomass production of every cultivation system were also analyzed. The results show that the flat-panel PBRs and the column PBRs are both preferred for large-scale biofuel production for high biomass productivity.
\end{abstract}

Keywords: microalgae; biofuel; energy consumption ratio (ECR); cultivation; photobioreactors

\section{Introduction}

With the growth of the world's population and the development of industrialization, humans' demand for energy is expanding. The world's energy consumption (583.90 EJ) is 3.75 times higher than it was 50 years ago (155.69 EJ), of which fossil energy takes the lead [1]. Today, the rate of burning fossil fuels is $136,762 \mathrm{TWh}$, significantly larger than the rate of compensation provided by nature [1]. The world could soon face a serious energy crisis if no modification is made to circumvent this trend. The massive combustion of fossil fuels emits a significant amount of greenhouse gases (GHGs), causing global warming [2]. The sixth assessment report (AR6) of the United Nations Intergovernmental Panel on climate change (IPCC2019) noted that 23\% of global carbon dioxide emitted from human activities led to an increase of $1.0{ }^{\circ} \mathrm{C}$ in global temperature over pre-industrial time. From 2030 to 2052 , the world temperature is expected to increase by $1.5^{\circ} \mathrm{C}$. Climate change has profound impacts on nature and human society. Consequently, there is an urgent need for an environmentally friendly, sustainable alternative to fossil fuels.

Biofuel is a source of renewable energy derived from biomass. It has huge energyreserves and meets $30 \%$ of global demand without disrupting traditional agricultural production and damaging the natural environment [3]. Biofuel's excellent properties make it a good representative of the new generation of energy. Microalgae are considered to be the greatest-potential bioenergy material to complement traditional fossil fuels because 
of their rapid growth rate, high oil content [4], high carbon sequestration efficiency [5], and low culture requirements [6]. Microalgae cells reportedly contain approximately $50 \%$ carbon, so it can be calculated by element conservation that $1.83 \mathrm{~kg}$ carbon dioxide can be fixed when producing $1 \mathrm{~kg}$ microalgae biomass [7]. Therefore, microalgae cultivation is an efficient carbon fixation method. In addition to their ability of carbon fixation, microalgae are believed to be a good feedstock for bioethanol, biodiesel, and biogas production [8]. However, current research suggests that the primary limit for the commercialization as well as the industrial production of microalgae biofuels is the high energy consumption in the production process [9]. Microalgae bioenergy cannot be widely produced in broad areas because it is high-cost for its large energy consumption [10]. In general, the production of microalgae biofuels includes two steps: the acquisition of microalgae raw biomass and the extraction of biomass to produce biofuel. Specifically, the step of acquisition includes cultivation and harvesting. Different cultivation and harvesting methods result in different energy consumption. In addition, the physical and chemical properties of microalgae raw bio-feedstock obtained by different cultivation and harvesting methods are different, resulting in different energy consumption in the following processes of the whole life cycle [8]. Therefore, comprehensive studies should be done evaluating different microalgae systems' energy consumption in cultivation and harvesting processes to select more economical systems for large-scale biofuel production.

Life cycle assessment (LCA) is a fundamental tool to evaluate the energy consumption and environmental footprint of biomass-based energies [9]. Many researchers have assessed the energy consumption during the whole life cycle of microalgal biofuels production with certain open ponds or PBR systems by LCA. However, to the best of our knowledge, there is no comparison of energy consumption among different cultivation systems based on numerous studies. Thus, this paper aimed to review the recent studies of the energy consumption of different cultivation systems, including open ponds, closed PBRs, and the hybrid cultivation system, in microalgae cultivation and the subsequent harvesting process. Furthermore, the microalgae growth parameters that affect the energy consumption such as the biomass concentration and areal biomass production were also analyzed. In this way, this review paper tried to select the suitable systems in providing abundant bio-feedstock for microalgal biofuels production and provide further information and advice for this industry.

\section{Microalgae Fuels Production Process}

Growing suspended in water, microalgae cells have efficient access to carbon dioxide, water, and nutrients, making them more efficient in converting solar energy [11]. Microalgae's high oil content makes it an ideal feedstock for renewable fuels, including biodiesel, biogas, bioethanol, bio-oil, etc. [12-14]. The carbohydrates contained in the microalgae cells are used to produce bioethanol, while the oil is used to produce biodiesel and the biomass can also be used directly in the production of methane or bio-oil [15].

As shown in Figure 1, the biofuel production process can be divided into upstream process (cultivation), midstream process (harvesting of microalgae biomass), and downstream process (biofuel production) [16]. A variety of cultivation systems can be used for microalgae autotrophic cultivation and mixed cultivation, mainly divided into open systems and closed systems. Harvesting is the process of concentrating the microalgae medium to convert the biomass more efficiently. The oil in microalgae is converted into biodiesel through transesterification [17]. Since the viscosity of microalgae oil is higher than that of petroleum diesel, it is necessary to reduce its original viscosity and increase its fluidity for use in diesel engines. The cellulose, sugar, or starch contained in the microalgae biomass is converted into bioethanol by fermentation [12]. Biomass of high moisture content can be converted directly to biogas averting drying via the following consecutive stages: (1) hydrolysis, (2) fermentation, (3) acetogenesis, and (4) methanogenesis [18]. Pyrolysis can be used to convert algae biomass to bio-oil, which is one of the most popular thermochemical conversion processes in recent times [11]. Pyrolysis can be classified into 
(1) conventional pyrolysis; (2) fast pyrolysis; and (3) flash pyrolysis based on differences in the temperature and the duration of this process [12].

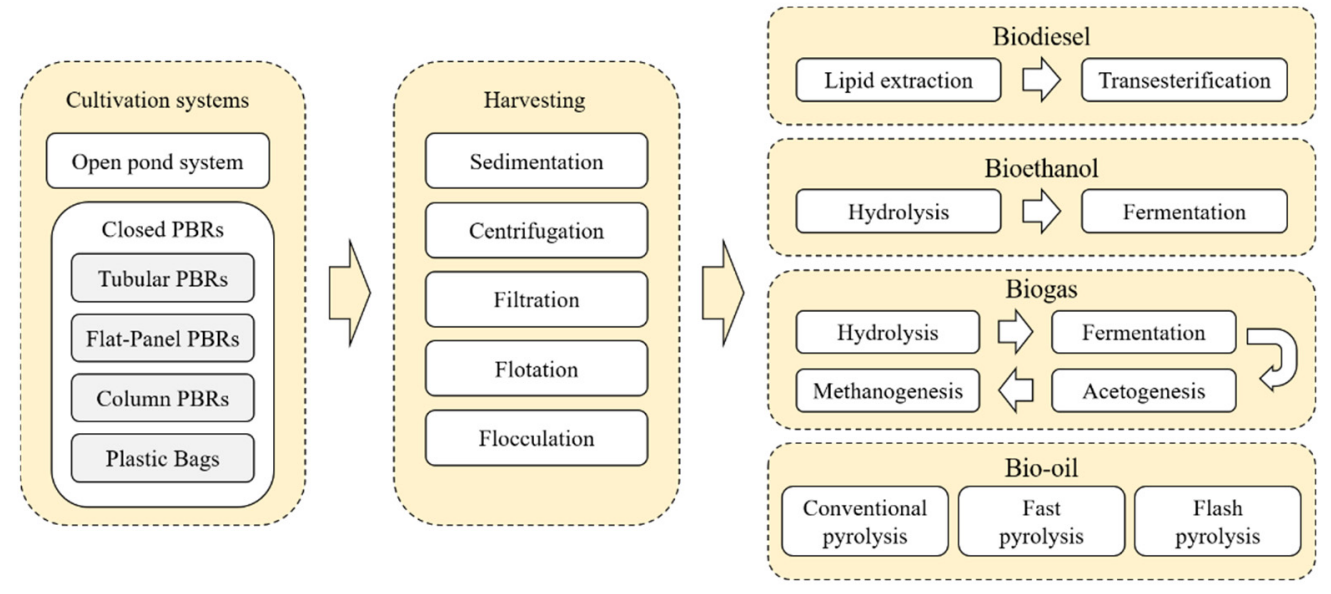

Figure 1. Production process for microalgae fuels.

\subsection{Cultivation}

The cultivation process of microalgae is one of the key factors affecting the biomass yield. The cultivation methods of microalgae mainly include heterotrophic cultivation and autotrophic cultivation, and some microalgae species can also be cultivated in a mixed way [19]. It is reported that photo-autotrophic cultivation is the most efficient microalgae cultivation method, which can maximize the photosynthesis rate and the cellular oil content [20]. The main influencing factors in the cultivation process are light, temperature, nutrition, $\mathrm{pH}$, and so on. The common cultivation systems include the open pond or open raceway pond system, flat-panel photobioreactor, tubular photobioreactor, column photobioreactor, plastic bag photobioreactor, and so on. As shown in Figure 2, the main energy-consuming parts of the cultivation process include the mixing and circulation of the medium, pumping of $\mathrm{CO}_{2}$ and nutrients, pumping of cooling water, and replenishment of evaporating water loss [9,21-24]. For water cooling, several options such as the passiveevaporative cooling system, direct immersion into thermoregulated pools, use of heat exchangers, dark sheet shading of photobioreactors, and placement in greenhouses are considered $[25,26]$. Different cooling strategies usually require a different amount of energy input, making it a primary component of energy consumption. Sometimes, additional heat and light are needed in cultivation $[27,28]$.

\subsubsection{Open Ponds System}

Since open ponds have the advantages of simple construction and low cost, most microalgae cultivation has been produced in open ponds irradiated by natural light in the past 60 years [29]. Circular or raceway are two common designs for open ponds. Generally, open ponds are designed as shallow ponds with a depth of about $0.3 \mathrm{~m}$ to ensure that a large number of microalgae can receive enough radiation to get a high growth rate [30]. In open ponds, pumps or paddle wheels are used as the driving force to circulate culture medium, which are the primary energy-consuming parts in cultivation. However, research shows that the efficiency of electric energy for the paddle wheel is generally low, only reaching about $10 \%-20 \%$ of electric energy input [31]. By improving the efficiency of the paddle wheel, researchers are expected to improve the energy utilization efficiency in the cultivation process. In the condition where the head difference is small, the efficiency of the paddle wheel can reach 75\% [32]. Moreover, the pumping of $\mathrm{CO}_{2}$ and nutrients, as well as the pumping of freshwater which is used to cool and replenish water lost by evaporation, are also the main parts of total energy consumption. In areas where the temperature is low, in order to maintain the suitable temperature for microalgae cultivation, additional 
heat is needed, so the heater is needed. For a cultivation of 2-day HRT (hydraulic retention times) [27], the maximum energy consumption of the open ponds system was $0.4 \mathrm{kWh} / \mathrm{m}^{3}$.

Razon et al. cultivated Nannochloropsis sp. in open ponds with saltwater to produce biogas. For $1.5 \mathrm{~m}^{3}$ of biogas production, the energy consumption was $151 \mathrm{MJ}$ and the net energy ratio (NER) of the whole process was 0.12 [33]. In addition, the use of pre-treated wastewater as nutrients and the reduction of fertilizer use in the cultivation process can lower the energy input to some degree [34].

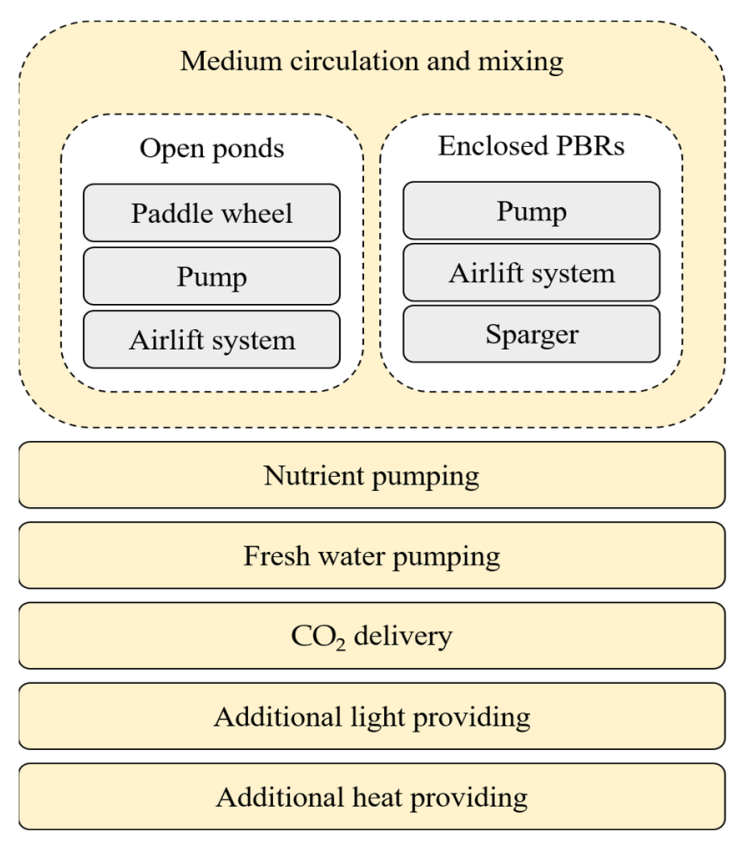

Figure 2. The main energy consuming parts of the cultivation process.

\subsubsection{Tubular PBRs}

Tubular PBRs are the most common type of PBRs, which are usually composed of tubes, degassing columns, and pumps [35]. As shown in Figure 3, the tubular PBR system is primarily composed of the degassing column that circulates air, the pump system, and cultivation tubes for microalgae. The microalgae culture flows from the degassing column to the tubes first, then returns to the degassing column in a circulation. Due to the relatively large light incident surface, tubular PBRs maximize the efficiency of radiation utilization and at the same time, are controllable [36]. Culture mixing, culture circulation, and gas pumping are the primary energy-consuming parts in the cultivation of the tubular PBRs. However, microalgae often adhere to the inner wall in the tubular PBRs system. This leads to a series of problems, such as increased flow resistance of culture medium in the tube, decreased transmittance, and increased energy consumption in the cultivation process. In order to solve these problems, several solutions are applied, such as increasing the flow rate of culture, expanding the inner diameter of the tubes, and using an automatic cleaning device [37]. Optimal temperatures for most species of microalgae are between 20 and $30^{\circ} \mathrm{C}$, and direct radiation results in a higher temperature in the PBRs than that in the outer environment [37]. Therefore, some measures should be taken to control the temperature in the PBRs from varying, such as using a temperature sensor to interconnect with external heat exchangers [38].

Dasan et al. [39] compared energy consumption between column PBRs and tubular PBRs. The energy consumption per 1 batch of biomass $(2924 \mathrm{~kg})$ produced by tubular PBRs in a low yield scenario was 10,973 kWh, and $4390 \mathrm{kWh}$ in a scenario with high yield, respectively, while that of column PBRs was only $1870 \mathrm{kWh}$ in the same low yield scenario and $275 \mathrm{kWh}$ in the high yield scenario. The main reason for this difference in energy consumption is that the tubular PBRs usually use pumps as the power of circulation, transferring culture between tubes and degassing column, which consumes a large amount 
of energy. Other PBRs such as column PBRs and flat-panel PBRs, however, use aeration devices to circulate the culture instead of pumps, with lower energy consumption.

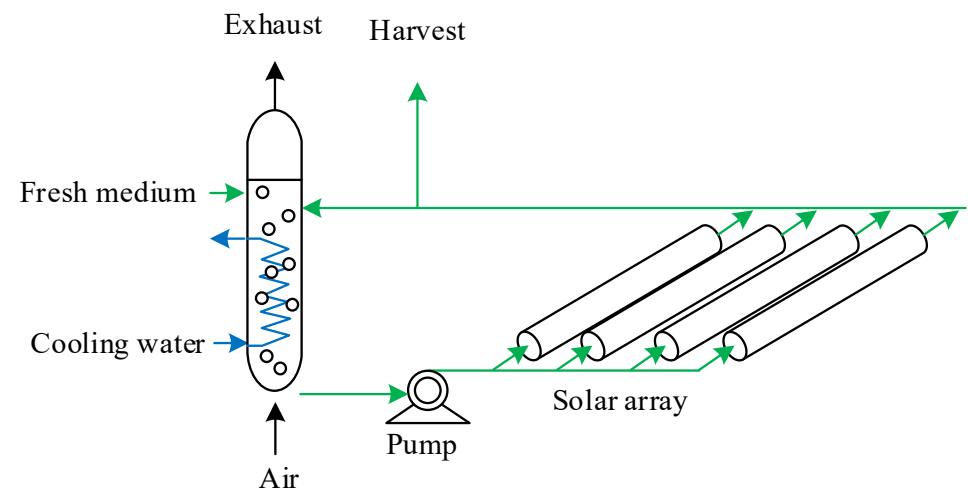

Figure 3. Schematics of a tubular PBR.

\subsubsection{Flat-Panel PBRs}

Another widely used PBR for microalgae cultivation is the flat-panel PBRs. The flatpanel PBRs is a rectangular plate made of transparent or translucent materials such as glass, plexiglass, polycarbonate, plastic bags, etc. [30]. It can be divided into the indoor type and the outdoor type. The flat-panel PBRs' structure is relatively simple, making it easy to clean, process, and operate. Its high specific surface area contributes to the better utilization of solar radiation by microalgae cells cultured, resulting in higher cell concentration [30]. Based on the differences in culture mixing methods, flat-panel PBRs can be divided into pump circulation PBRs and airlift PBRs. The schematics of pump circulation PBRs and airlift PBRs are presented in Figure 4. The pump circulation PBRs use the pumps to circulate the culture medium, while the airlift PBRs use the airlift system to mix the culture medium evenly. At present, many novel flat-panel PBRs, which have good prospects in the large-scale industrial production of microalgae bio-feedstock, have been developed [40].

Airlift PBRs have many advantages, such as less shear stress on microalgae cells, higher gas-liquid mass transfer rate, and higher mixing efficiency, so the energy consumption of flat plate airlift PBRs is relatively low. In the same case, the energy consumption per unit output is about one-tenth of that of tubular PBRs [41,42].

Brentner et al. [41] compared the energy consumption of tubular PBRs and flat-panel PBRs. For every unit of microalgae biodiesel containing $10^{4} \mathrm{MJ}$ of energy, the energy consumption of tubular PBRs was $43,900 \mathrm{kWh}$ and that of flat-panel PBRs was only $544 \mathrm{kWh}$. Ozkan et al. [42] stated that the energy consumption of open ponds PBRs, tubular PBRs, and flat-panel PBRs in a microalgae bio-feedstock life cycle were $9.18 \mathrm{MJ} / \mathrm{kg}, 385.71 \mathrm{MJ} / \mathrm{kg}$, and $16.96 \mathrm{MJ} / \mathrm{kg}$ respectively.

\subsubsection{Column PBRs}

Column PBR systems can be divided into two types: bubble column PBRs and airlift column PBRs. As is shown in Figure 5, column PBRs include a separation column type, a coaxial tube type, an external circulation type, and a separation type. Regarding airlift column PBRs, they are composed of an ascending zone and a descending zone. The gas enters the PBRs through the bottom of the ascending zone, which makes the culture medium at the bottom of the PBRs contain a large amount of gas, thus making it of low density. Due to the influence of gravity, the gas at the bottom will automatically rise and dissipate from the exhaust port. After the gas is dissipated, the gas content in the microalgae culture medium decreases and the density increases. At this time, the gas will return from the descending zone to the bottom of the ascending zone, thus forming a cycle [43]. 


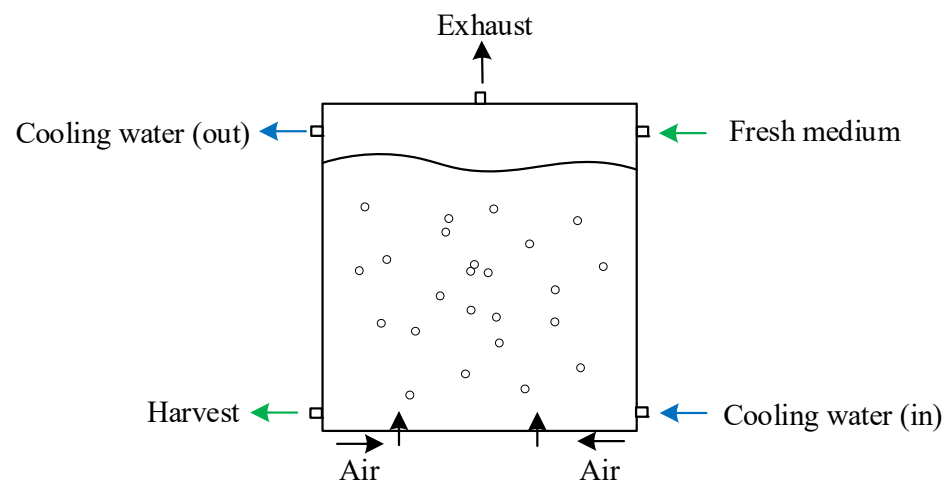

a

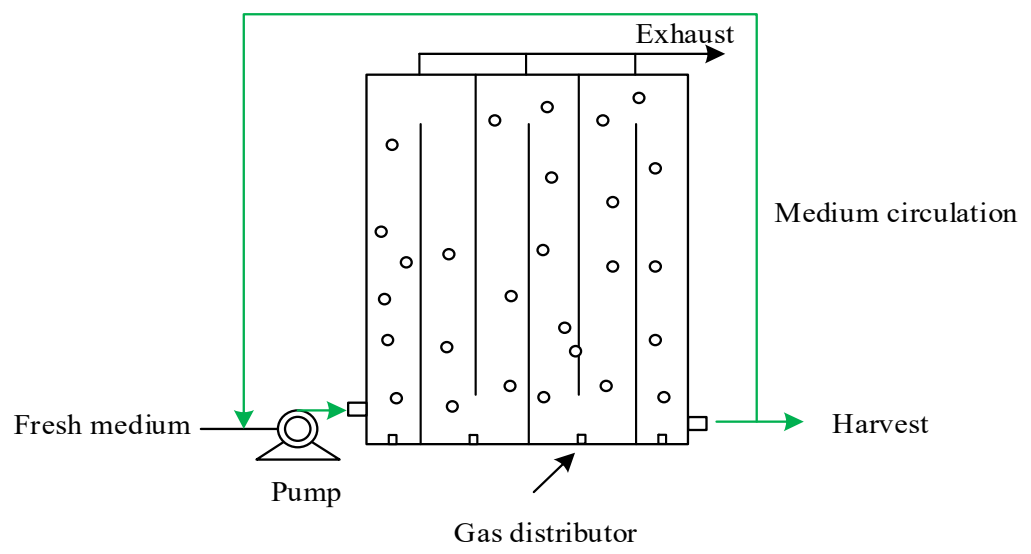

b

Figure 4. Schematics of two common flat-panel PBRs: (a) pump circulation PBR and (b) airlift PBR.
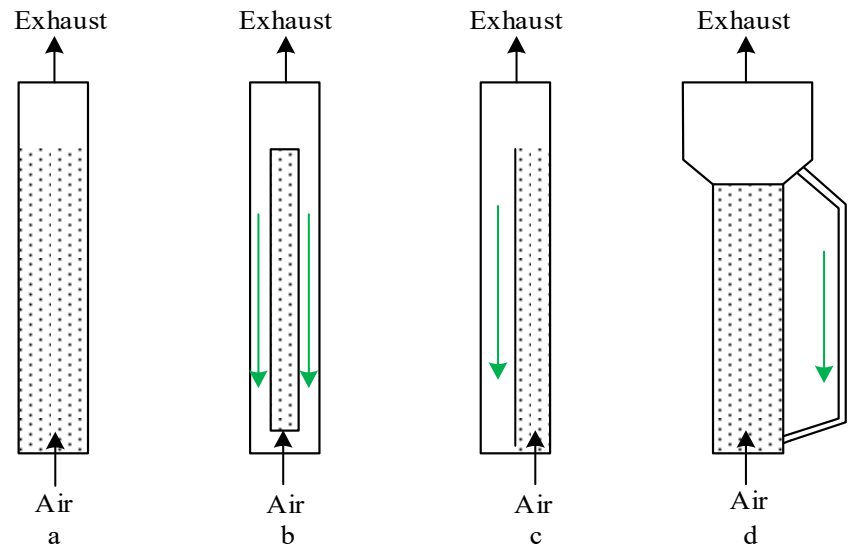

Figure 5. Several kinds of airlift column PBRs: (a) separation column type, (b) coaxial tube type, (c) external circulation type, and (d) separation type.

To better utilize sunlight radiation, the diameter of the airlift column PBRs should not exceed $0.2 \mathrm{~m}$, preventing the low light utilization efficiency of the PBRs center [37]. In addition, the height of column PBRs should be less than $4 \mathrm{~m}$. On one hand, column PBRs generally use transparent materials, which often have low strength and cannot be overstressed. On the other hand, it is to avoid mutual masking between PBRs in large-scale industrial production of microalgae. Airlift column PBRs are one of the most suitable devices for the large-scale cultivation of microalgae [44]. However, the large investment 
and cleaning difficulty will increase the difficulty of the large-scale application of column airlift PBRs [45].

A pilot-scale bubble column PBRs was used to cultivate microalga Phaeodactylum tricornutum; the energy consumption per $1 \mathrm{~kg}$ production of biodiesel was $1.07 \mathrm{kWh}$ [46].

\subsubsection{Plastic Bag PBRs}

The plastic bag PBR consists of one or more groups of suspended plastic bags. It has the advantages of easy access to raw materials and low cost. Therefore, it has good commercial prospects and gained worldwide focus [37]. In the plastic bag PBR system, different volumes of plastic bags for specific demands can be made. Chen et al. used a single 5 L plastic bag PBR to cultivate Chlorella on a large scale [47], and Abomohra et al. used a set of culture systems consisting of 20 polyethylene plastic bags with a length of $2 \mathrm{~m}$, a width of $20 \mathrm{~cm}$, and a thickness of $0.2 \mathrm{~cm}$ [48]. For plastic bag PBRs with a larger volume, the temperature inside can be controlled by the water surrounding, which is a way to reduce the cost. The plastic bag PBRs can even be surrounded by seawater for microalgae cultivation. The reason for this step is obvious. On one hand, the temperature of the medium can be controlled stably due to large conduction of water; and on the other hand, waves in the sea can act as a natural mixer as it shares a similar mixing effect for the bio-feedstock, which can reduce the energy consumption caused by pumps and aeration chambers, lowering the investment [49].

To promote the growth of microalgae cells in plastic bag PBRs, aerators or pumps are used to circulate microalgae culture medium; blowers can be used to supplement $\mathrm{CO}_{2}$ as well. In addition, pumps can be used to transport water to cool the culture and supplement the evaporation loss of culture. The energy consumption of plastic bag PBRs with pumps and blowers is $382.7 \mathrm{GJ} /$ ha per year (producing $36 \mathrm{t}$ of Tetraselmis suecica sp. biomass) [50]. Lamps can also be used to provide a continuous light source for plastic bags, and the energy consumption of the light source is about $2.17 \mathrm{MJ} / \mathrm{g}$ biomass [28].

However, there are many disadvantages of the plastic bag PBR system. First of all, the plastic bag PBR is composed of soft plastic bags. The effect of gravity may cause the distortion and deformation of plastic bags, which will lead to the occurrence of photoinhibition or the inhibition of the growth of microalgae cells in some areas due to the poor mixing effect. Secondly, the material strength of the plastic bag PBR is low, which may lead to leakage, which limits the possibility of large-scale industrial development of plastic bag PBRs. Thirdly, the service life of plastic bag PBRs is short. Due to frequent cleaning, the service life span of the bag is shortened to a certain extent, which is not economical in the long run. At the same time, the uneconomical treatment of plastic bags also needs to be improved.

\subsubsection{Hybrid Cultivation System}

Although investment in open ponds systems is lower than that of closed photobioreactor systems, open ponds systems are easy to be polluted by bacteria and protozoa [51]. In contrast, although a closed photobioreactor has less chance of getting polluted, its sophisticated manufacture and operation process costs more. Therefore, the hybrid cultivation system, a combination of both systems, is recommended to reduce overall costs and to increase the microalgae biomass productivity [52]. At the first stage, a large number of stable and robust inoculums were obtained by a closed photobioreactor, and the exogenous pollution of other microorganisms was controlled. In the second stage, microalgae were cultivated on a large scale in the open pond system to obtain a large amount of biomass [53]. The two-stage hybrid cultivation method can give full play to the advantages of the two types of systems and reduce the cost of microalgae cultivation. It is a reliable way to achieve efficient and large-scale cultivation of microalgae.

A hybrid cultivation system including a paddle wheel raceway pond and an airlift PBR to cultivate microalgae has a relatively low energy consumption, which is lower than $5.8 \mathrm{MJ} / \mathrm{kg}$ biomass [54]. 
In conclusion, Table 1 shows the advantages, disadvantages and applications of the cultivation systems.

Table 1. Advantages, disadvantages, and applications of various types of photobioreactors $[55,56]$.

\begin{tabular}{|c|c|c|c|c|}
\hline Closed PBR System & Types & Advantages & Disadvantages & Applications \\
\hline & $\begin{array}{l}\text { Tubular } \\
\text { PBR }\end{array}$ & $\begin{array}{l}\text { - Large effective light surface } \\
\text { area } \\
\text { - } \quad \text { High biomass productivity. }\end{array}$ & $\begin{array}{l}\text { Light deficit in the tubes } \\
\text { - } \quad \text { High energy consumption } \\
\text { Occupying a large area for } \\
\text { tubes } \\
\text { - } \quad \text { gH and } \mathrm{CO}_{2} \text { concentration } \\
\text { gradient in the culture } \\
\mathrm{O}_{2} \text { build-up } \\
\text { - } \quad \text { Cells adhering to the wall }\end{array}$ & $\begin{array}{l}\text { Suitable for outdoor } \\
\text { cultivation. }\end{array}$ \\
\hline & $\begin{array}{l}\text { Flat-Panel } \\
\text { PBR }\end{array}$ & $\begin{array}{ll}\text { - } & \text { Easy to process, clean } \\
\text { - } & \text { Low cost } \\
& \text { Different light path can be } \\
\text { designed according to the } \\
\text { needs } \\
\text { - } \quad \text { Large surface area } \\
\text { Uniform mixing of culture }\end{array}$ & $\begin{array}{l}\text { Difficult to process in large } \\
\text { industrial scale. }\end{array}$ & $\begin{array}{c}\text { Suitable for } \\
\text { small-scale/laboratory } \\
\text { cultivation. }\end{array}$ \\
\hline & $\begin{array}{l}\text { Column } \\
\text { PBR }\end{array}$ & $\begin{array}{ll}\text { - } & \text { High mass transfer efficiency } \\
\text { - } & \text { Uniform mixing } \\
\text { - } & \text { Lmall shear force } \\
\text { - } & \text { Simple operation }\end{array}$ & $\begin{array}{ll}\text { - } & \text { Small volume } \\
\text { - } & \text { High cost } \\
& \text { Difficult to process in large } \\
\text { industrial scale }\end{array}$ & $\begin{array}{l}\text { Suitable for small-scale } \\
\text { /laboratory cultivation. }\end{array}$ \\
\hline & $\begin{array}{c}\text { Plastic bag } \\
\text { PBR }\end{array}$ & $\begin{array}{l}\text { - } \quad \text { Low water consumption } \\
\text { how cost in microalgae } \\
\text { harvesting process }\end{array}$ & $\begin{array}{l}\text { - } \quad \text { Membrane pollution } \\
\text { Requires microalgae culture to } \\
\text { be adsorbable }\end{array}$ & $\begin{array}{l}\text { For large scale } \mathrm{CO}_{2} \\
\text { fixation and sewage } \\
\text { treatment. }\end{array}$ \\
\hline Open PBR system & Open Pond & $\begin{array}{ll}\text { - } & \text { Simple structure } \\
\text { - } & \text { Low cost } \\
\text { - } & \text { Simple operation }\end{array}$ & $\begin{array}{l}\text { - Covering large agricultural } \\
\text { area } \\
\text { - Low effective land utilization } \\
\text { rate }\end{array}$ & $\begin{array}{l}\text { Current commercial } \\
\text { production of microalgae. }\end{array}$ \\
\hline
\end{tabular}

\subsection{Harvesting}

The harvesting process concentrates and dewaters the microalgae culture medium to obtain a high concentration slurry for the next production process. In this process, the concentration of microalgae culture medium is concentrated from $0.1-2.0 \%$ to $10-30 \%$ of total suspended solids (TSS). The harvesting process is usually divided into two steps. The first step is concentration. In this step, the concentration of microalgae culture medium will be concentrated to about $7 \%$. The second step is dehydration. After this step, the concentration of microalgae culture medium will reach about $15 \%$ [57]. This process consumes a lot of energy, accounting for about $20-30 \%$ of the total energy input [10]. Therefore, reducing the energy input and investment of harvesting is an essential prerequisite for large-scale biofuel production. Common harvest process methods mainly include flocculation, flotation, electric treatment, filtration, centrifugation, and sedimentation, which can also be combined flexibly in practical production. To reduce costs and improve harvesting efficiency, flocculation is usually performed first, followed by centrifugation and filtration processes.

\subsubsection{Sedimentation}

Sedimentation is a technique to harvest microalgae biomass by gravity. The cell density and cell size of microalgae have significant effects on sedimentation efficiency [58]. Sedimentation technology is more suitable for the harvesting of species with higher cell density, such as Melosira sp., while not being suitable for microalgae species with low cell density, such as Microcystis aeruginosa. Various factors can affect the sedimentation performance, such as temperature, microalgae species, etc. [58]. The process of sedimentation is often time-consuming and low efficiency. To solve this problem in industrial production, 
sedimentation is usually achieved by combining the use of flocculation, centrifugation, and other technologies to reduce the sedimentation time and improve production efficiency [59].

\subsubsection{Filtration}

Filtration is a standard solid-liquid separation technology. In the process of microalgae harvesting, the culture solution passes the filter membrane due to the effects of gravity, pressure, and vacuum force, while microalgae cells are intercepted by the membrane and concentrated into biomass. Based on the characteristics of the solution, kinetic conditions, and membrane kinds, filtration can be divided into microfiltration $(0.1-10 \mu \mathrm{m})$, macrofiltration $(10 \mu \mathrm{m})$, dead-end filtration, ultrafiltration $(0.02-0.2 \mu \mathrm{m})$, tangential flow filtration, vacuum filtration, and pressure filtration [60].

Compared with other harvesting technologies, filtration technology harvests a better quality bio-feedstock because no chemicals are added during filtration, with little damage to cells. Filtration is a more energy-saving way of harvesting microalgae bio-feedstock. The energy consumption of concentrating microalgae culture to 75 times that of initial culture medium $(150 \mathrm{~g} / \mathrm{L})$ is about $0.3-0.7 \mathrm{kWh} / \mathrm{m}^{3}$ by filtration [61], and the energy consumption of concentrating microalgae culture to 151 times that of its initial culture medium is about $2.15 \mathrm{kWh} / \mathrm{m}^{3}$ [62]. In order to collect bio-feedstock more efficiently with higher recovery, additional energy input is needed. Brentner et al. [41] used the harvest method of filtration under chamber pressing to produce $10^{4} \mathrm{MJ}$ microalgae biodiesel, consuming $2200 \mathrm{kWh}$ of energy, with a biomass recovery reaching 95\%. Razon et al. used a combined method of gravity sedimentation and microfiltration to produce $2.6 \mathrm{~m}^{3}$ biogas, requiring $99.7 \mathrm{MJ}$ of energy for the harvest process [33].

\subsubsection{Centrifugation}

Centrifugation technology is the improvement of gravity sedimentation technology, which can separate microalgae cells from the culture medium by centrifugal force instead of gravity. Although there are some problems in large-scale applications, such as high energy consumption, high cost of equipment, operation, and maintenance, centrifugation is still the most widely used harvesting technology for its high biomass recovery, usually higher than 95\% [63]. Centrifugation can be used in the harvest of many kinds of microalgae. Since there is no need to add flocculants and chemicals in centrifugation, the quality of raw bio-feedstock collected after centrifugation is high.

However, the energy consumption of the centrifugation process is high, normally reaching $14-20 \%$ of the total energy consumption of the microalgae biofuel's energy life cycle [64]. Brentner et al. [41] compared the energy consumption of centrifugation and flocculation in the scenario of $95 \%$ of the cell recovery. To produce $10^{4} \mathrm{MJ}$ of microalgae biodiesel in production, the energy required for centrifugation was $2500 \mathrm{kWh}$, while it was only $250 \mathrm{kWh}$ for flocculation. A similar difference existed in two methods whether they were carried with $\mathrm{pH}$ regulations or adding different flocculants like aluminum or chitosan. Tredici et al. produced 36 tons of bio-feedstock with an annual energy consumption for centrifugation of $81.6 \mathrm{GJ} / \mathrm{ha}$ [50]. Gwenny et al. stated that the energy consumption required for centrifugation was $1.4 \mathrm{kWh} / \mathrm{m}^{3}$, with a recovery of $97 \%$ [65]. In order to reduce the energy consumption of centrifugation, the culture medium should be settled or flocculated in advance to improve the initial concentration of culture medium. Xin et al. [66] used flocculation before centrifugation for the treatment of bio-feedstock of Chlorella sp., and the energy consumption for the combined process was only about $1 \mathrm{kWh} / \mathrm{m}^{3}$.

\subsubsection{Flotation}

Flotation technology is a harvesting technology that collects biomass by producing a large number of microbubbles (bubble diameter $<0.1 \mathrm{~mm}$ ) that attach to the surface of microalgae cells as a carrier. Microalgae cells, which are attached with microbubbles then float to the liquid surface, are harvested as bio-feedstock [67]. Flotation does not require additional pressure, so its energy consumption is relatively low, making it a popular 
technology in microalgae harvest process. However, in order to produce microbubbles, it is necessary to add some surfactants to change the hydrophobicity of the microalgal cellular surface. In that way, the cell is more easily combined with the bubbles to improve the recovery [68]. However, these surfactants generally have bad effects on the growth of microalgae and pollute the downstream process. Therefore, the microbubbles should be better produced by physical flotation methods such as dissolved air flotation and electrolytic flotation instead of chemical methods. In this way, the bio-feedstock collected is not severely damaged or polluted.

\subsubsection{Flocculation}

As the surface of microalgae cells is negatively charged, surface charge neutralization is applied to be the primary mechanism involved to harvest microalgae of flocculation [69]. Raw microalgae bio-feedstock harvested by the flocculation process has high economic value and recovery, greatly reducing energy input. Therefore, flocculation technology is another primary harvesting method for microalgae. Flocculation methods are normally divided into chemical flocculation, physical flocculation, and biological flocculation from the perspective of flocculants used [70].

Chemical flocculation, as mentioned, is to add chemical substances, including inorganic and organic substances, into the culture medium to accelerate the sedimentation of microalgae cells. Chitosan is a commonly used kind of polymer flocculant. Chlorella biomass recovery by chemical flocculation with chitosan reaches more than $90 \%$ in 2-3 $\mathrm{min}$ [23]. Physical flocculation mainly includes electric flocculation and magnetic flocculation. Compared with chemical flocculation, physical flocculation avoids the problems of culture pollution and harmful byproducts caused by chemical additives. Biological flocculation primarily uses the viscous substances and biosurfactants produced by the organism itself or during its metabolism to make the microalgae cells aggregate with each other through netting or bond bridging to be finally collected as bio-feedstock [71]. Certain fungi, bacteria, and microorganisms and their active substances are conducive to the flocculation of biomass as well.

Some microalgae cells can flocculate naturally without adding flocculants. These cells secrete synthetic glycosides or polysaccharides and other active substances to their surface. The interaction among the surrounding microalgae cells leads to the auto-aggregation and auto-flocculation of microalgae cells [72]. For these microalgae cells, the chemical additive is needless in the harvesting process. The biomass collected in this way is praised for its high quality as well as its high recovery.

Dasan et al. used aluminum as flocculant in the flocculation process before centrifugation. For the open ponds system, column PBR system, and tubular PBR system, the energy consumption of cultivating one batch $(2924 \mathrm{~kg})$ of microalgae bio-feedstock was $542.8 \mathrm{kWh}, 11.83 \mathrm{kWh}$, and $5.225 \mathrm{kWh}$, respectively, which was mainly because of the different concentrations of microalgae culture medium in different cultivation systems [39].

The advantages and disadvantages of various algae harvesting techniques introduced are shown in Table 2.

Table 2. Advantages and disadvantages of various algae harvesting techniques $[51,73,74]$.

\begin{tabular}{|c|c|c|}
\hline Harvesting Technique & Advantages & Disadvantages \\
\hline Sedimentation & $\begin{array}{l}\text { - } \quad \text { Low energy consumption } \\
\text { - Happens naturally }\end{array}$ & $\begin{array}{ll}\text { - } & \text { Time-consuming } \\
\text { - } & \text { Low harvest efficiency } \\
\text { - } & \text { High water content }\end{array}$ \\
\hline Centrifugation & $\begin{array}{ll}\text { - } & \text { Fast, effective } \\
\text { - } & \text { High recovery } \\
\text { - } & \text { Suitable for large microalgae species }\end{array}$ & $\begin{array}{l}\text { - } \quad \text { High energy consumption } \\
\text { - } \quad \text { High operating cost and equipment cost } \\
\text { - } \quad \text { Not suitable for large-scale harvesting }\end{array}$ \\
\hline
\end{tabular}


Table 2. Cont

\begin{tabular}{|c|c|c|}
\hline Harvesting Technique & Advantages & Disadvantages \\
\hline Filtration & $\begin{array}{ll}\text { - } & \text { High recovery } \\
\text { - } & \text { No chemical demand } \\
\text { - } & \text { Low energy consumption } \\
\text { - } & \text { Small shear force } \\
\text { - } & \text { Time-saving } \\
\text { - } & \text { Water can be recycled }\end{array}$ & $\begin{array}{l}\text { - High energy consumption } \\
\text { - } \quad \text { Requires pressured or vacuum environment } \\
\text { - Not suitable for microalgae with small cells }\end{array}$ \\
\hline Flotation & $\begin{array}{ll}\text { - } & \text { Suitable for large-scale harvesting } \\
\text { - } & \text { Low cost } \\
\text { - } & \text { Time-saving }\end{array}$ & $\begin{array}{l}\text { - } \quad \text { Needs surfactant } \\
\text { - High cost for preparing microbubble }\end{array}$ \\
\hline Flocculation & $\begin{array}{ll}\text { - } & \text { Fast, simple } \\
\text { - } & \text { Suitable for large-scale harvesting } \\
\text { - } & \text { Less damage to cells, suitable for } \\
& \text { various microalgae } \\
\text { - } & \text { Low energy consumption }\end{array}$ & $\begin{array}{l}\text { - High cost of flocculants and operators } \\
\text { - } \quad \text { Difficult to separate flocculants from culture }\end{array}$ \\
\hline
\end{tabular}

\subsection{Drying}

Normally, the water content is still high in raw bio-feedstock after harvesting. Therefore, further treatment is needed to dry the bio-feedstock for biofuel production. Drying treatment is important not only because dried bio-feedstock is more convenient for biofuel transportation, but also because it prevents the reproduction of harmful microorganisms, extending the storage time for biofuels. In the production of microalgae biodiesel, it is necessary to first extract the oil from the dried biomass so that the transesterification reaction performs successfully later. The oil extraction rate of dried bio-feedstock is significantly higher than that of wet bio-feedstock [75].

Typical drying methods include rotary, spray, solar, freeze, cross-flow, vacuum, flashing, incinerator, and toroidal [75]. However, from an economic point of view, the huge energy demand in the drying process has brought great challenges to the feasibility of microalgae biofuel production [76-78]. The energy consumption of traditional drying methods accounts for approximately $59.3-85 \%$ of total energy input.

Brentner et al. [41] compared the total energy consumption of drying the bio-feedstock of Scenedesmus dimorphus sp. to produce 1 unit of biodiesel $\left(10^{4} \mathrm{MJ}\right)$, in Phoenix, AZ, US. The energy consumption for the drying process varied from $14,885 \mathrm{MJ}$ to $16,360 \mathrm{MJ}$, covering a primary proportion of total energy consumed. Beal et al. [54] dried Staurosira sp. biomass in airlift PBR with ring dryers, consuming $212,406.48 \mathrm{MJ} /$ day, which equaled $47 \%$ of the total energy input $(453,891.46 \mathrm{MJ} /$ day), to produce $2563.69 \mathrm{~kg} /$ day of lipid and $13,896.04 \mathrm{~kg} /$ day of non-lipid biomass. In Chile, the bio-feedstock of Phaeodactylum tricornutum sp., cultivated in bubble column PBR, was dried applying a freeze-drier technology with a recovery of $80 \%$, consuming $40.79 \mathrm{kWh}$, nearly twice the energy input for the harvesting and cultivation process in generating $12 \mathrm{~kg}$ of dried biomass [46].

Freeze drying is commonly regarded as a way of preserving complete cellular components because when microalgae are dried at low temperature, their cellular biological activity and internal degrading enzyme activity are also weakened so that their cells remain unchanged for a long time [79]. However, freeze drying requires a long processing time and expensive equipment, which makes it not suitable for the industrial scale of the drying process of microalgae bio-feedstock [80]. For the spray drying and rotary drying, a diluted solution or spray of microalgae culture is heated into dry powder. They are favored for their rapid water removal rate and less damage to microalgae cells. However, the operation of spray drying and rotary drying is complicated. Moreover, spray drying and rotary drying require not only large investment in the drying plants and equipment, but also taking care of the relatively high operating cost [79]. In order to excellently reduce the energy consumption in the drying process, solar energy can be used for drying. Solar 
drying was applied to the bio-feedstock of Chlorella sp. cultivated in flat-plate PBR, an effective drying method that consumes almost no electricity [66].

To reduce energy consumption, wet bio-feedstock (medium containing more than $80 \%$ of moisture) can be directly extracted by enzymatic hydrolysis, without experiencing the drying process. Furthermore, enzymatic hydrolysis can be carried out under mild conditions so that many active cellular substances can be maintained during the process.

In addition, microalgae bio-feedstock with certain moisture can be fermented directly to produce bioethanol, biogas, etc. In this way, the energy demand greatly reduces. For biogas produced without drying the bio-feedstock, it even provides extra energy for the drying process and reduces net energy input by $84 \%$, an alternative for traditional power sources [76]. Biogas is primarily composed of $\mathrm{CH}_{4}$ and $\mathrm{CO}_{2}$. The production of biogas is an anaerobic digestion process, including hydrolysis, fermentation, and methanogenesis. In the hydrolysis stage, the compound is decomposed into soluble sugars. Then, the fermentation bacteria transform them into alcohols, acetic acid, volatile fatty acids, and gases containing $\mathrm{H}_{2}$ and $\mathrm{CO}_{2}$. Then, the main compound is metabolized into $\mathrm{CH}_{4}$ and $\mathrm{CO}_{2}$ by methanogens. Microalgae bioethanol is usually generated from starch, cellulose, and other carbohydrates in microalgae bio-feedstock by microbial fermentation and distillation. The residue after oil extraction can also be used as the substrate for ethanol fermentation.

In this section, the mechanism as well as the energy consumption parts in cultivation, harvesting, and drying processes are illustrated. Different technologies and systems applied affect not only the energy input for these parts, but also the energy input of the whole life cycle process. To better quantify the energy consumption of different cultivation systems, comparisons are made in the next section.

\section{Literature Review Results}

\subsection{The Energy Consumption Ratio of Cultivation}

This review aims to examine the energy consumption of different cultivation systems via the parameter of energy consumption ratio (ECR), which can be calculated by the total direct energy input in the cultivation process divided by the energy contained in microalgae biomass produced. ECR shows the direct energy required to produce a unit of microalgae biomass. It is feasible to compare the data from different studies through this parameter. It can be calculated by the following equation:

$$
E C R=E_{\text {total input }} / L H V_{\text {biomass }} \cdot \text { Productivity }
$$

$E_{\text {total input }}$ is the total direct energy input in the cultivation process, including the energy consumption for circulating the culture and pumping the water, $\mathrm{CO}_{2}$, and nutrients into the systems, and the additional heat or light provided in some studies, while the energy contained in materials input is not taken into consideration. The energy contained in microalgae biomass is represented by the low heating value (LHV) of produced microalgae biomass, which is estimated to be $22.2 \mathrm{MJ} / \mathrm{kg}$ [50].

Figure 6 shows the energy consumption ratio of different cultivation systems, and the data being analyzed are shown in Table 3. Compared with most closed PBR systems, open ponds require less energy, with an average energy consumption ratio of 0.07 . The hybrid cultivation systems use both PBR and open pond systems to cultivate microalgae, so its energy consumption ratio is between that of most PBR systems and open pond systems, with an average of 0.17. In PBR systems, flat-panel PBRs and bubble column PBRs have the lowest average energy consumption ratio, while tubular PBR and plastic-bag PBR have the higher energy consumption ratio.

For tubular PBR, more energy is needed to not only maintain the circulation of culture medium, but also obtain higher growth efficiency by better gas-liquid transmission [81]. From Figure 7, it can be concluded that an average biomass concentration of $6.43 \mathrm{~kg} / \mathrm{m}^{3}$ can be obtained by tubular PBR, due to its large available surface area for illumination [82]. However, low areal biomass productivity is obtained by this system, suggesting low culture volume per area. This is because, on one hand, tubes are shortened to transport $\mathrm{CO}_{2}$, and 
$\mathrm{O}_{2}$ as well as to regulate $\mathrm{pH}$ more efficiently. On the other hand, the diameter of tubes is reduced to prevent the impact of photo limitation [37]. Its low areal productivity even increases the demand for more land in large-scale bio-feedstock production.

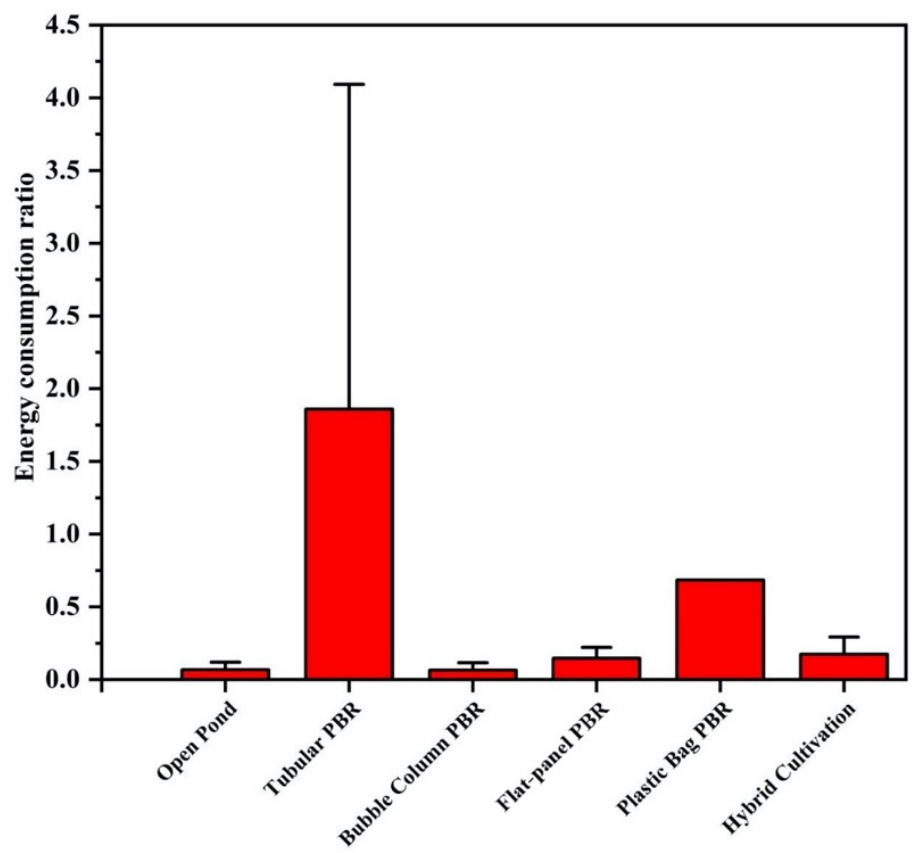

Figure 6. Comparison of energy consumption ratio of different cultivation systems.

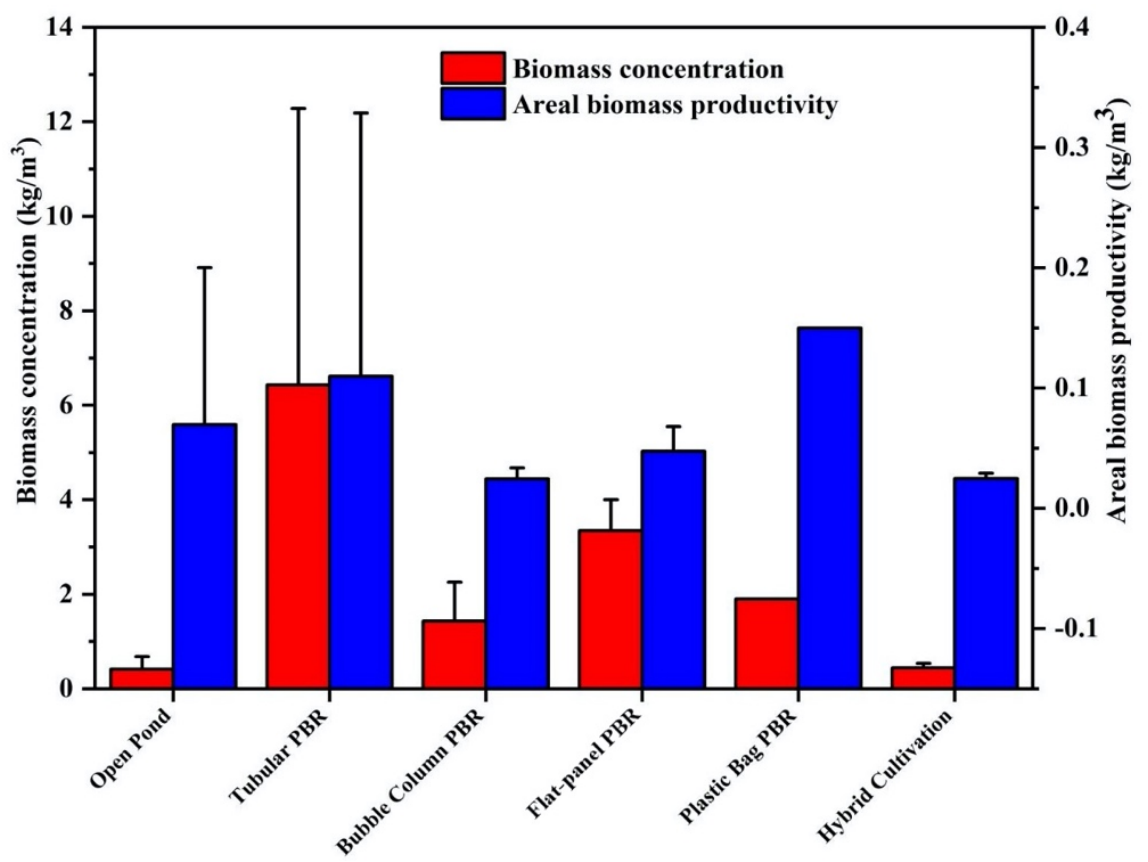

Figure 7. Comparison of biomass concentration and areal biomass productivity of different cultivation systems.

The average energy consumption ratio of plastic bag PBR is the highest, reaching 0.68. Tredici et al. [50] used blowers to circulate culture medium, which is the main part of the energy consumption. However, although it consumes a lot of energy with relatively low biomass concentration, plastic-bag PBR has great potential for microalgae cultivation for its high areal biomass productivity and low cost. 
The energy consumption ratio of column PBRs is the lowest with only 0.06. Although column PBRs gain low average biomass concentration, they have relatively large areal biomass productivity. This may be because no internal structures that consume energy are required to be installed, except for spargers [35]. Therefore, the transporting of $\mathrm{CO}_{2}$ and mixing the culture can be done at the same time.

Results suggest that the most suitable system for industrial scale biofuel production may be flat-panel PBRs, which have the lowest energy consumption ratio and the highest areal biomass productivity. Flat-panel PBRs have a large illumination surface area, so the photosynthetic efficiencies are high [83]. However, flat-panel PBRs are not profitable or sustainable for commercial-scale cultivation, because to control culture temperature and ensure transmission efficiency, the volume of a flat-panel PBRs is difficult to enlarge [84]. Similar findings are observed in several studies. Dasan et al. [39] compared the energy consumption in the life cycle of the open pond, column PBR, and tubular PBR, and in the cultivation process, the energy consumption of open pond is the lowest while the tubular PBR is the highest. Brentner et al. [41] found that compared with annular PBR and tubular PBR, flat-panel PBR consumes less energy when applied to microalgae cultivation.

PBR systems generally obtain higher biomass concentration than open pond systems do. For the hybrid system, since the PBR system is used only to produce high-purity microalgae in the early stage, and in the following stage microalgae are usually cultivated in open pond systems, the biomass concentration of hybrid systems is similar to that of open pond systems.

Microalgae bio-feedstock is concentrated by harvesting to further produce biofuels. Therefore, the difference in biomass concentration directly affects the energy consumption of the subsequent steps. As such, although the open pond system consumes less energy on average, it is not necessarily the most energy-saving from the view of the whole life cycle.

Table 3. Energy consumption ratio, biomass concentration, and areal biomass production of different cultivation systems.

\begin{tabular}{|c|c|c|c|c|c|c|c|}
\hline Site Location & $\begin{array}{l}\text { Microalgae } \\
\text { Species }\end{array}$ & Cultivation System & $\begin{array}{c}\text { Energy } \\
\text { Consumption } \\
\text { Ratio }^{\mathrm{a}}\end{array}$ & $\begin{array}{c}\text { Biomass } \\
\text { Concentration } \\
\left(\mathrm{kg} / \mathrm{m}^{3}\right)\end{array}$ & $\begin{array}{l}\text { Areal biomass } \\
\text { Production } \\
\left(\mathrm{kg} / \mathrm{m}^{2} / \mathrm{d}\right)\end{array}$ & Notes & References \\
\hline - & Chlorella vulgaris & Tubular PBR & $0.61^{\mathrm{b}}$ & 8.00 & 0.02 & $\begin{array}{l}\text { Low biomass } \\
\text { production }\end{array}$ & [39] \\
\hline - & Chlorella vulgaris & Tubular PBR & $0.24^{\mathrm{b}}$ & 20.00 & 0.03 & $\begin{array}{l}\text { High biomass } \\
\text { production }\end{array}$ & [39] \\
\hline- & Chlorella vulgaris & Open raceway pond & $0.02^{b}$ & 1.00 & 0.06 & $\begin{array}{l}\text { Low biomass } \\
\text { production }\end{array}$ & [39] \\
\hline - & Chlorella vulgaris & Open raceway pond & $0.03^{b}$ & 0.48 & 0.44 & $\begin{array}{l}\text { High biomass } \\
\text { production }\end{array}$ & [39] \\
\hline- & Chlorella vulgaris & Bubble column PBR & $0.10^{\mathrm{b}}$ & 0.75 & 0.01 & $\begin{array}{l}\text { Low biomass } \\
\text { production }\end{array}$ & [39] \\
\hline- & Chlorella vulgaris & Bubble column PBR & $0.02^{b}$ & 2.59 & 0.04 & $\begin{array}{l}\text { High biomass } \\
\text { production }\end{array}$ & [39] \\
\hline Concepcion, Chile & $\begin{array}{l}\text { microalga } P \text {. } \\
\text { tricornutum, }\end{array}$ & Bubble column PBR & $0.01^{\mathrm{c}}$ & 0.96 & $0.02^{\mathrm{d}}$ & - & [46] \\
\hline Phoenix, AZ, US & $\begin{array}{l}\text { Scenedesmus } \\
\text { dimorphus }\end{array}$ & Open raceway pond & 0.06 & 0.47 & 0.05 & - & [41] \\
\hline Phoenix, AZ, US & $\begin{array}{l}\text { Scenedesmus } \\
\text { dimorphus }\end{array}$ & Flat-Panel PBR & 0.05 & 4.00 & 0.07 & - & {$[41]$} \\
\hline Bissau, Guinea & - & Open raceway pond & 0.06 & - & $0.02^{\mathrm{e}}$ & - & [85] \\
\hline Huelva, Spain & - & Open raceway pond & 0.07 & - & $0.02 \mathrm{e}$ & - & [85] \\
\hline Uppsala, Sweden & - & Open raceway pond & 0.19 & - & $0.01^{\mathrm{e}}$ & - & [85] \\
\hline Bissau, Guinea & - & Tubular PBR & 0.32 & - & $0.03^{\mathrm{e}}$ & - & [85] \\
\hline Huelva, Spain & - & Tubular PBR & 0.36 & - & $0.02^{\mathrm{e}}$ & - & {$[85]$} \\
\hline Uppsala, Sweden & - & Tubular PBR & 0.74 & - & $0.01^{\mathrm{e}}$ & - & [85] \\
\hline Tuscany, Italy & Tetraselmis suecica & Plastic bag PBR & $0.68^{b}$ & - & $0.15^{\mathrm{f}}$ & - & [50] \\
\hline- & Chlorella vulgaris & Open raceway pond & $0.03^{b}$ & - & 0.02 & Waste water & [86] \\
\hline - & Chlorella vulgaris & Open raceway pond & $0.02^{\mathrm{b}}$ & - & 0.02 & Fresh water & [86] \\
\hline Texas/Hawaii, US & Staurosira sp. & $\begin{array}{l}\mathrm{PBR}+\text { Open raceway } \\
\text { pond }\end{array}$ & $0.41^{\mathrm{b}}$ & 0.36 & 0.02 & $\begin{array}{l}\text { Low-N, } \\
\text { paddle-wheel pond } \\
\text { circulation } 24 \mathrm{~h} / \text { day }\end{array}$ & [54] \\
\hline Texas/Hawaii, US & Staurosira sp. & $\begin{array}{c}\mathrm{PBR}+\text { Open raceway } \\
\text { pond }\end{array}$ & $0.15^{b}$ & 0.36 & 0.02 & $\begin{array}{l}\text { Low-N, airlift pond } \\
\text { circulation } 16 \mathrm{~h} / \text { day }\end{array}$ & {$[54]$} \\
\hline
\end{tabular}


Table 3. Cont

\begin{tabular}{|c|c|c|c|c|c|c|c|}
\hline Site Location & $\begin{array}{l}\text { Microalgae } \\
\text { Species }\end{array}$ & Cultivation System & $\begin{array}{c}\text { Energy } \\
\text { Consumption } \\
\text { Ratio }^{\mathrm{a}}\end{array}$ & $\begin{array}{c}\text { Biomass } \\
\text { Concentration } \\
\left(\mathrm{kg} / \mathrm{m}^{3}\right)\end{array}$ & $\begin{array}{l}\text { Areal biomass } \\
\text { Production } \\
\left(\mathrm{kg} / \mathrm{m}^{2} / \mathrm{d}\right)\end{array}$ & Notes & References \\
\hline Texas/Hawaii, US & Staurosira sp. & $\begin{array}{c}\mathrm{PBR}+\text { Open raceway } \\
\text { pond }\end{array}$ & $0.09^{b}$ & 0.62 & 0.03 & $\begin{array}{l}\text { High-N, airlift pond } \\
\text { circulation } 16 \mathrm{~h} / \text { day }\end{array}$ & [54] \\
\hline Texas/Hawaii, US & Desmodesmus sp. & $\begin{array}{c}\mathrm{PBR}+\text { Open raceway } \\
\text { pond }\end{array}$ & $0.13^{\mathrm{b}}$ & 0.45 & 0.02 & $\begin{array}{l}\text { High- } \mathrm{N} \text {, airlift pond } \\
\text { circulation } 16 \mathrm{~h} / \text { day }\end{array}$ & [54] \\
\hline Texas/Hawaii, US & Desmodesmus sp. & $\begin{array}{c}\text { PBR }+ \text { Open raceway } \\
\text { pond }\end{array}$ & $0.09^{b}$ & 0.45 & 0.02 & $\begin{array}{l}\text { High-N, airlift pond } \\
\text { circulation } 12 \mathrm{~h} / \text { day }\end{array}$ & [54] \\
\hline Fort Saskatchewan & - & Open raceway pond & $0.04^{b}$ & - & - & & [87] \\
\hline Fort Saskatchewan & - & Column PBR & $0.13^{b}$ & - & - & & [87] \\
\hline - & $\begin{array}{l}\text { Nannochloropsis } \\
\text { sp. }\end{array}$ & Open raceway pond & 0.12 & 0.35 & 0.01 & & [22] \\
\hline- & $\begin{array}{l}\text { Nannochloropsis } \\
\text { sp. }\end{array}$ & Tubular PBR & 5.04 & 1.02 & 0.03 & & {$[22]$} \\
\hline- & $\begin{array}{l}\text { Nannochloropsis } \\
\text { sp. }\end{array}$ & Flat-Panel PBR & 0.22 & 2.7 & 0.03 & & [22] \\
\hline
\end{tabular}

'- ' represents the information not mentioned in the articles. ${ }^{\text {a }}$ Energy consumption ratio is the total energy consumption (MJ) divided by energy contained in microalgae biomass (MJ). ${ }^{\mathrm{b}}$ Calculated with the energy contained in microalgae biomass, which is $22.2 \mathrm{MJ} / \mathrm{kg}$ [50]. ${ }^{\mathrm{c}} \mathrm{A}$ total of $12 \mathrm{~kg}$ of dried microalgae biomass is required when producing $1 \mathrm{~kg}$ of biodiesel. ${ }^{\mathrm{d}}$ Calculated by biomass concentration multiplied by volume of microalgae culture and divided by occupied area. ${ }^{\mathrm{e}}$ Calculated with a 300 -day cultivation season per year. ${ }^{\mathrm{f}}$ Calculated with a 240-day cultivation season per year.

In this part, the net energy ratio (NER) of the whole life cycle of microalgae biofuel is also taken into consideration. The NER is defined as energy output divided by the energy input, which is used to measure the energy efficiency. Although the difference of cultivation methods only affects energy consumption in the cultivation and harvesting process, it is meaningful to compare the total energy consumption of different cultivation systems over the whole life cycle to figure out whether a system is profitable and sustainable. Generally, an energy production process is considered to be profitable only if the value of NER is greater than 1.0 [88,89]. The biomass NER and biofuel NER results of present studies are in Figures 8 and 9 , respectively $[21,22,39,50,54,85,87,90,91]$. The biomass NER values differ between 0.2 and 8.34 , and the biofuel NER values vary between 0.07 and 3.05. The NER value differs by the category of cultivation system. The lowest value is observed in the tubular PBR system, while the highest is in the open pond system. Flat-panel PBR seems to be the most energy-saving closed system from the figures. It should be noted that the NER results of different studies change widely for a particular cultivation system, and the difference of NER is also observed with different processes in certain studies. In addition, from Figures 8 and 9, it can be seen that recent studies did not gain higher NER values than the earlier ones, illustrating that more energy-efficient technologies were not applied to the life cycle analysis (LCA) studies.

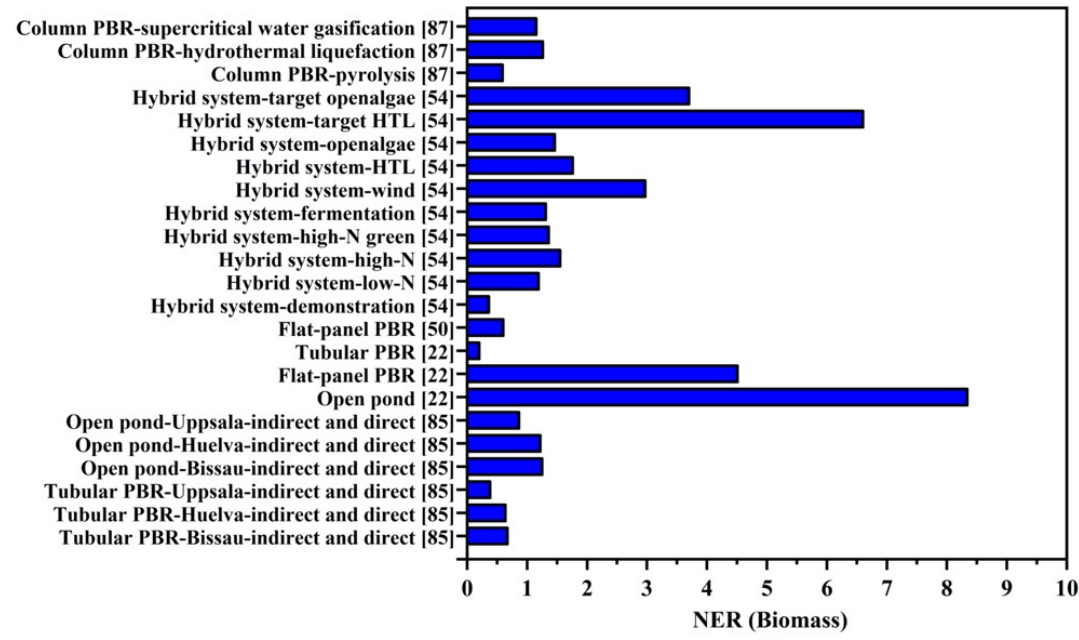

Figure 8. Comparison of NER values for microalgae biomass from recent studies. 


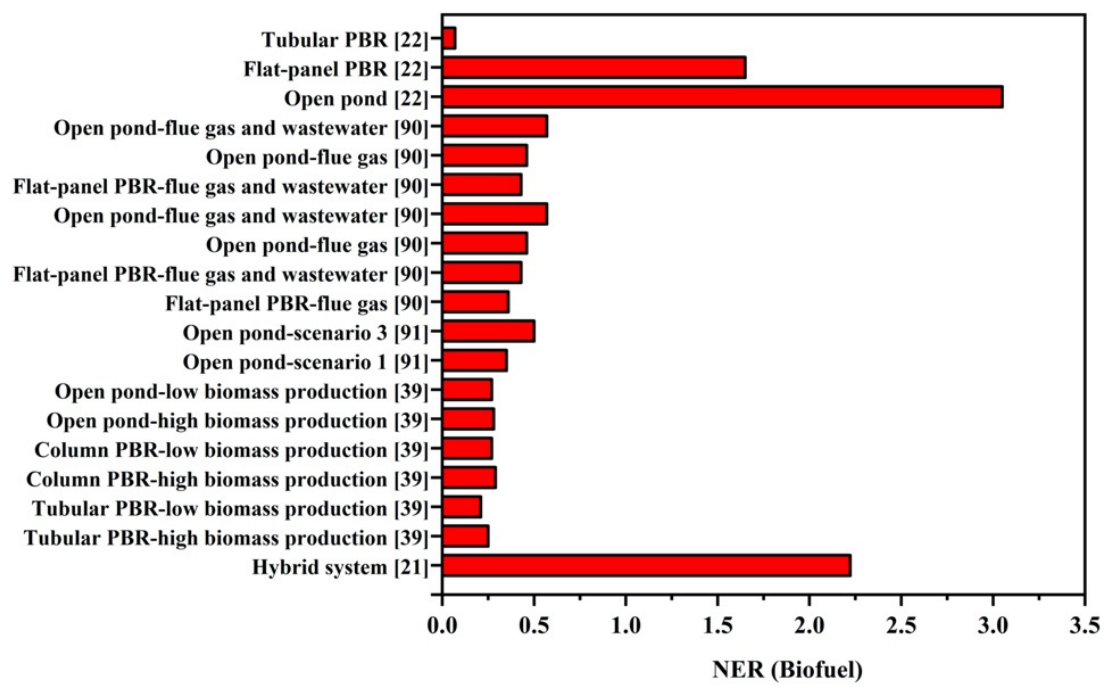

Figure 9. Comparison of NER value for microalgae biofuel from recent studies.

\subsection{The Energy Consumption Ratio of Harvesting}

The ECR of harvesting is also calculated by Equation (1), and the total direct energy input includes the electricity and heat consumption in this process. The materials input is not considered. The literature review results of the energy consumption ratio of different harvesting technologies are shown in Table 4.

Centrifugation is a common harvesting method, but it has relatively high direct energy consumption, with an energy consumption ratio of $0.18-0.9[41,50,85,92]$. The concentration of microalgae in the culture solution before harvesting was the main factor affecting the energy consumption of the centrifugation process. When the concentration of microalgae before harvesting changed from 0.2 to $4 \mathrm{~kg} / \mathrm{m}^{3}$, the energy consumption ratio changed from 0.33 to $0.067[85,92]$. Different cultivation systems have different concentrations of microalgae. Compared with closed PBR systems, the concentration of microalgae in the open pond system is lower. This is the reason that although the energy consumption of the open pond system is low in cultivation, its energy consumption is significantly higher in the harvesting process. Taking the energy consumption of harvesting into consideration, some PBR systems such as the column PBR and the flat-panel PBR obtain a high concentration of microalgae in the harvesting process, having great potential in industrial scale bio-feedstock production. It is also possible to use other technologies to pre-concentrate the microalgae culture and increase the concentration of slurry, thus reducing the energy consumption of the process. Bva et al. [92] and Jonker et al. [85] settled the culture before centrifugation to reduce the energy consumption of the harvesting process by $90 \%$.

The energy consumption of filtration is generally small, whether for press filtration or ultra/micro filtration. Like centrifugation, concentrations are different as obtained by different filtration methods, resulting in different energy consumption. The energy consumption ratio is $0.003-0.018$ when bio-feedstock cultivated in column PBR and an open pond system is filtrated by ultra/micro filtration [87]. The energy consumption for the filtration of culture from the open pond system is $0.002-0.003$ when pre-concentrated by settling [54]. Since the energy consumption of flocculation alone without pre-treatment is high, about 0.09 , it is not advocated for industrial use. One possible economic solution might be using the combined method of flocculation-settling-centrifugation, with an energy consumption ratio varying from 0.002 to 0.058 for different cultivation systems. 
Table 4. The energy consumption ratio of different harvesting technologies.

\begin{tabular}{|c|c|c|c|c|c|c|}
\hline Microalgae Species & Cultivation System & Harvesting Technology & $\begin{array}{l}\text { Pre-Harvesting } \\
\text { Microalgae } \\
\text { Concentration } \\
\left(\mathrm{kg} / \mathrm{m}^{3}\right)\end{array}$ & $\underset{\text { Ratio }^{\mathrm{a}}}{\text { Energy }}$ & Notes & References \\
\hline $\begin{array}{l}\text { Microalga } P \text {. } \\
\text { Tricornutum, }\end{array}$ & Bubble column PBR & Centrifugation & 0.96 & $0.274^{b c}$ & & [46] \\
\hline Chlorella Vulgaris & Open raceway pond & $\begin{array}{l}\text { Flocculation }(\text { Alum })+\text { Settling }+ \\
\text { Centrifugation }\end{array}$ & 0.48 & $0.058^{b}$ & $\begin{array}{l}\text { Scenario 1: Low } \\
\text { biomass production }\end{array}$ & [39] \\
\hline Chlorella Vulgaris & Open raceway pond & $\begin{array}{c}\text { Flocculation(Alum) }+ \text { Settling }+ \\
\text { Centrifugation }\end{array}$ & 1 & $0.033^{b}$ & $\begin{array}{l}\text { Scenario 2: High } \\
\text { biomass production }\end{array}$ & [39] \\
\hline Chlorella Vulgaris & Bubble column PBR & $\begin{array}{c}\text { Flocculation (Alum) }+ \text { Settling }+ \\
\text { Centrifugation }\end{array}$ & 0.75 & $0.007^{b}$ & $\begin{array}{l}\text { Scenario 3: Low } \\
\text { biomass production }\end{array}$ & [39] \\
\hline Chlorella Vulgaris & Bubble column PBR & $\begin{array}{l}\text { Flocculation }(\text { Alum })+\text { Settling }+ \\
\text { Centrifugation }\end{array}$ & 2.59 & $0.002^{b}$ & $\begin{array}{l}\text { Scenario } 4 \text { : High } \\
\text { biomass production }\end{array}$ & [39] \\
\hline Chlorella Vulgaris & Tubular PBR & $\begin{array}{l}\text { Flocculation }(\text { Alum })+\text { Settling }+ \\
\text { Centrifugation }\end{array}$ & 8 & $0.003^{\mathrm{b}}$ & $\begin{array}{l}\text { Scenario 3: Low } \\
\text { biomass production }\end{array}$ & [39] \\
\hline Chlorella vulgaris & Tubular PBR & $\begin{array}{l}\text { Flocculation (Alum) }+ \text { settling }+ \\
\text { centrifugation }\end{array}$ & 20 & $0.002^{b}$ & $\begin{array}{l}\text { Scenario } 4 \text { : High } \\
\text { biomass production }\end{array}$ & [39] \\
\hline Scenedesmus dimorphus & - & Centrifugation & - & $0.325^{b}$ & & [41] \\
\hline Scenedesmus dimorphus & - & Chamber press filtration & - & $0.286^{\mathrm{b}}$ & & [41] \\
\hline Scenedesmus dimorphus & - & Chamber press filtration & - & $0.286^{\mathrm{b}}$ & & [41] \\
\hline Scenedesmus dimorphus & - & $\begin{array}{l}\text { Flocculation(Alum/ph- } \\
\text { lime/chitosan) }\end{array}$ & - & $0.033^{\mathrm{b}}$ & & [41] \\
\hline- & Open raceway pond & Centrifugation & 0.2 & 0.330 & & [85] \\
\hline- & Open raceway pond & Settling + centrifugation & 0.2 & 0.027 & & [85] \\
\hline Scenedesmus dimorphus & - & Chamber press filtration & - & $0.286^{\mathrm{b}}$ & & [41] \\
\hline Scenedesmus dimorphus & - & $\begin{array}{l}\text { Flocculation(Alum/ph- } \\
\text { lime/chitosan) }\end{array}$ & - & $0.033^{\mathrm{b}}$ & & [41] \\
\hline- & Open raceway pond & Centrifugation & 0.2 & 0.330 & & [85] \\
\hline - & Open raceway pond & Settling + centrifugation & 0.2 & 0.027 & & [85] \\
\hline - & Tubular PBR & Centrifugation & 4 & 0.067 & & [85] \\
\hline- & Tubular PBR & Settling + centrifugation & 4 & 0.027 & & [85] \\
\hline Tetraselmis suecica & Plastic bag PBR & Centrifugation & - & $0.176^{\mathrm{b}}$ & & [50] \\
\hline Chlorella sp. & Flat-Panel PBR & $\begin{array}{l}\text { Flocculation + settling + } \\
\text { centrifugation }\end{array}$ & 2 & $0.009^{b d}$ & & [66] \\
\hline Staurosira sp. & $\begin{array}{l}\mathrm{PBR}+\text { Open } \\
\text { raceway pond }\end{array}$ & Settling + centrifuge & 0.36 & $0.081^{b}$ & $\begin{array}{l}\text { Low-N, paddle-wheel } \\
\text { pond circulation } \\
24 \mathrm{~h} / \text { day }\end{array}$ & [54] \\
\hline Staurosira sp. & $\begin{array}{l}\mathrm{PBR}+\text { Open } \\
\text { raceway pond }\end{array}$ & Settling + filter press & 0.36 & $0.003^{b}$ & $\begin{array}{l}\text { Low-N, airlift pond } \\
\text { circulation } 16 \mathrm{~h} / \text { day }\end{array}$ & [54] \\
\hline Staurosira sp. & $\begin{array}{l}\mathrm{PBR}+\text { Open } \\
\text { raceway pond }\end{array}$ & Settling + filter press & 0.618 & $0.002^{b}$ & $\begin{array}{l}\text { High-N, airlift pond } \\
\text { circulation } 16 \mathrm{~h} / \text { day }\end{array}$ & [54] \\
\hline- & PBR & $\begin{array}{l}\text { Ultra/micro filtration } \\
\text { membrane + centrifugation }\end{array}$ & - & $0.011^{b}$ & & [87] \\
\hline- & Open raceway pond & $\begin{array}{l}\text { Ultra/micro filtration } \\
\text { membrane + centrifugation }\end{array}$ & - & $0.062^{b}$ & & [87] \\
\hline Chlorella vulgaris & Open raceway pond & Flocculation + centrifugation & - & $0.088^{\mathrm{b}}$ & Waste water & [86] \\
\hline Chlorella vulgaris & Open raceway pond & Flocculation + centrifugation & - & $0.139^{\mathrm{b}}$ & Fresh water & [86] \\
\hline
\end{tabular}

'-' represents the information not mentioned in the articles. ${ }^{\text {a }}$ Energy consumption ratio is the total energy consumption (MJ) divided by energy contained in microalgae biomass (MJ). ${ }^{b}$ Calculated with the energy contained in microalgae biomass, which is $22.2 \mathrm{MJ} / \mathrm{kg}$ [50]. ${ }^{\mathrm{c}} \mathrm{A}$ total of $12 \mathrm{~kg}$ of dried microalgae biomass is required when producing $1 \mathrm{~kg}$ of biodiesel. ${ }^{\mathrm{d}}$ Calculated with a 320-day cultivation season per year.

\section{Challenges and Future Development}

Many studies have shown that the NER of microalgae biofuel production is lower than $1.0[37,88,89]$, which means unprofitable for long term operation. However, microalgae are rich in protein, polysaccharides, fatty acids, vitamins, pigments, etc., so some high-margin secondary products can be obtained during the energy production. In addition, considering the carbon sequestration ability of microalgae, it is a feasibly profitable way for energy companies in carbon trading. At present, the large-scale production of microalgae biofuel has already gained some progress. The company named Algenol Biotech LLC in the United States applied the enclosed PBR system to produce 8000 gallons of liquid biofuel per acre per year [93]. Another company named SyntheticGenomics Inc in the United States also applied the closed PBR system to produce 1600 gallons per acre per year of lipid [93]. 
Technological advances in the algae industry are changing rapidly and with the progress of technology, the energy consumption of the whole biofuel system will reduce and the cost for producing unit biofuel will decrease as well. Thus, the technology improvement and innovation of cultivation systems may be the future research directions. For example, increasing the light path or light dilution inside the flat-panel and column PBR systems and the ratio of suspended culture to total volume improves the photosynthesis efficiency [94]. Many factors display important impacts on photosynthesis efficiency including the vertical or horizontal distribution of the column PBR or the tubular PBR and the angles of the flat-panel PBR [95]. The drying technology should also be improved to reduce energy demands for other processes in the biofuel production cycle. Vicente et al. [96] and Kita et al. [97] used direct transesterification of fungal lipids or thermal pretreatment of B. braunii after the solvent extraction to reduce extra energy input. Last but not least, the location where microalgae receive a high average amount of radiation and require less water for cooling to a moderate temperature should be carefully selected [98].

It is worth noticing that an innovative PBR system, the photovoltaic coupled PBR system, is currently emerging as a highly economic system. Nwoba et al. [99] applied a photovoltaic coupled vertical flat-panel PBR (1 ha) to obtain an annual areal biomass productivity of $66 \mathrm{t} / \mathrm{ha}$ and a NER of 3.0, while $0.6-7.1$ of NER was obtained by traditional PBR systems $[50,100]$. Its excellent ability in utilizing excess solar radiation might be a future way in large-scale and sustainable biofuel production. It also helps solve the problem of overheating and high energy input for microalgae biofuel production. Morales et al. [101] evaluated optimal integration of biomass production with photovoltaic panels in open raceway pond systems ( $145 \mathrm{ha}$ ) and suggested that $20 \%$ coverture of photovoltaic panels is the best scenario from an energetic and environmental perspective, with a NER of 2.9 and annual areal biomass productivity of $62.1 \mathrm{t} / \mathrm{ha}$.

As for research needs, the future work will focus on analyzing the energy consumption ratio of the whole life cycle process including the extraction, transesterification, and different compositions of biofuel produced. Moreover, the influence of changes in growth parameters for different cultivation systems should be considered including the bioreactor volume and the ratio of area illuminated.

\section{Conclusions}

This paper compared the energy consumption of several cultivation systems that are commonly used in large-scale microalgae production. Unlike previous studies, we compared as many cultivation systems as we could, aiming to analyze the energy consumption of different systems comprehensively. The open pond system is the most energy-saving and most widely used one of all the systems, but considering the limitations of open ponds such as low productivity, uncontrollability, and contamination susceptibility, it is necessary to develop outdoor PBRs suitable for mass biofuel production. Flat-panel PBRs consume less energy and produce more biomass per unit area than other PBRs, which will be a suitable cultivation system if the problems of scaling can be solved. Moreover, column PBRs show slightly lower areal productivity and lower biomass concertation than flat-panel PBRs, but they are easier to scale up. Therefore, the flat-panel PBR as well as the column PBR are both preferred for large-scale biofuel production for high biomass productivity. As for the harvesting methods, the mixed process flexibly combining flocculation, settling, and centrifugation is the most energy efficient. The concentration of microalgae before harvesting observably influences the energy consumption of harvesting; thus, PBRs that can produce a higher concentration of culture medium show more potential economically.

For companies that plant microalgae on a large scale, gradually replacing current open raceway ponds with enclosed flat-panel PBR and column PBR systems will be a feasible way to increase productivity and reduce cost. Flexible combinations of flat-panel PBRs and column PBRs should be carried out for different growth situations. In addition to biofuels, producing some higher value byproducts is also profitable for companies. 
However, the results of this work are mainly based on the data reported in the literatures published in recent years, so some delays may be found due to the rapid development of microalgae industry. The energy consumption of some innovative PBRs will be studied in the future. Furthermore, energy consumption is directly related to the cost of companies, so the economic assessment among different cultivation systems will be done in the future, too.

Author Contributions: Conceptualization, methodology, data curation and formal analysis, M.C., Y.C. and Q.Z.; writing-original draft preparation, M.C. and Y.C.; visualization, Y.C.; writing-review and editing, M.C., Y.C. and Q.Z; supervision, project administration and funding acquisition, Q.Z. All authors have read and agreed to the published version of the manuscript.

Funding: This work was financially supported by the National Natural Science Foundation of China (31270748,31470707 and 41701139), Hubei Key Laboratory of Water System Science for Sponge City Construction (Wuhan University) (2020-05).

Institutional Review Board Statement: Not applicable.

Informed Consent Statement: Not applicable.

Data Availability Statement: Not applicable.

Conflicts of Interest: The authors declare no conflict of interest.

\section{References}

1. International Energy Agency. Key World Energy Statistics; International Energy Agency: Paris, France, 2020.

2. Töbelmann, D.; Wendler, T. The impact of environmental innovation on carbon dioxide emissions. J. Clean. Prod. 2020, 244, 118787. [CrossRef]

3. Koonin, S.E. Getting Serious About Biofuels. Science 2006, 311, 435. [CrossRef]

4. Singh, U.B.; Ahluwalia, A.S. Microalgae: A promising tool for carbon sequestration. Mitig. Adapt. Strateg. Glob. Chang. 2013, 18, 73-95. [CrossRef]

5. Xu, X.; Gu, X.; Wang, Z.; Shatner, W.; Wang, Z. Progress, challenges and solutions of research on photosynthetic carbon sequestration efficiency of microalgae. Renew. Sustain. Energy Rev. 2019, 110, 65-82. [CrossRef]

6. Gouveia, L.; Oliveira, A.C. Microalgae as a raw material for biofuels production. J. Ind. Microbiol. Biotechnol. 2009, 36, $269-274$. [CrossRef] [PubMed]

7. Chisti, Y. Biodiesel from microalgae. Biotechnol. Adv. 2007, 25, 294-306. [CrossRef] [PubMed]

8. Su, Y.; Song, K.; Zhang, P.; Su, Y.; Cheng, J.; Chen, X. Progress of microalgae biofuel's commercialization. Renew. Sustain. Energy Rev. 2017, 74, 402-411. [CrossRef]

9. Saranya, G.; Ramachandra, T.V. Energy Conversion and Management: X 8 (2020) 100065 Life Cycle Assessment of Biodiesel from Estuarine Microalgae; Elsevier: Amsterdam, The Netherlands, 2021.

10. Barros, A.I.; Goncalves, A.L.; Simoes, M.; Pires, J.C.M. Harvesting techniques applied to microalgae: A review. Renew. Sustain. Energy Rev. 2015, 41, 1489-1500. [CrossRef]

11. Sirajunnisa, A.R.; Surendhiran, D. Algae-A quintessential and positive resource of bioethanol production: A comprehensive review. Renew. Sustain. Energy Rev. 2016, 66, 248-267. [CrossRef]

12. Lee, O.K.; Lee, E.Y. Sustainable production of bioethanol from renewable brown algae biomass. Biomass Bioenergy 2016, 92, 70-75. [CrossRef]

13. Suganya, T.; Varman, M.; Masjuki, H.H.; Renganathan, S. Macroalgae and microalgae as a potential source for commercial applications along with biofuels production: A biorefinery approach. Renew. Sustain. Energy Rev. 2016, 55, 909-941. [CrossRef]

14. Veillette, M.; Giroir-Fendler, A.; Faucheux, N.; Heitz, M. Biodiesel from microalgae lipids: From inorganic carbon to energy production. Biofuels 2018, 9, 175-202. [CrossRef]

15. Saad, M.G.; Dosoky, N.S.; Zoromba, M.S.; Shafik, H.M. Algal Biofuels: Current Status and Key Challenges. Energies 2019, 12, 1920. [CrossRef]

16. Yin, Z.; Zhu, L.; Li, S.; Hu, T.; Li, B. A comprehensive review on cultivation and harvesting of microalgae for biodiesel production: Environmental pollution control and future directions. Bioresour. Technol. 2020, 301, 122804. [CrossRef]

17. Kandiyoti, R.; Herod, A.; Bartle, K.; Morgan, T. Fossil fuels and renewables. In Solid Fuels and Heavy Hydrocarb. Liquids, 2nd ed.; Elsevier Science: Amsterdam, The Netherlands, 2017; pp. 1-9. [CrossRef]

18. Adeniyi, O.M.; Azimov, U.; Burluka, A. Algae biofuel: Current status and future applications. Renew. Sustain. Energy Rev. 2018, 90, 316-335. [CrossRef]

19. Daneshvar, E.; Yong, S.O.; Tavakoli, S.; Sarkar, B.; Bhatnagar, A. Insights into upstream processing of microalgae: A review. Bioresour. Technol. 2021, 329, 124870. [CrossRef] 
20. Cesário, M.T.; Da Fonseca, M.M.R.; Marques, M.M.; de Almeida, M.C.M.D. Marine algal carbohydrates as carbon sources for the production of biochemicals and biomaterials. Biotechnol. Adv. 2018, 36, 798-817. [CrossRef]

21. Hossain, N.; Zaini, J.; Mahlia, T. Life cycle assessment, energy balance and sensitivity analysis of bioethanol production from microalgae in a tropical country. Renew. Sustain. Energy Rev. 2019, 115, 109371. [CrossRef]

22. Jorquera, O.; Kiperstok, A.; Sales, E.A.; Embiruçu, M.; Ghirardi, M.L. Comparative energy life-cycle analyses of microalgal biomass production in open ponds and photobioreactors. Bioresour. Technol. 2010, 101, 1406-1413. [CrossRef]

23. Rashid, N.; Rehman, S.U.; Han, J.I. Rapid harvesting of freshwater microalgae using chitosan. Process. Biochem. 2013, 48, 1107-1110. [CrossRef]

24. Issarapayup, K.; Powtongsook, S.; Pavasant, P. Flat panel airlift photobioreactors for cultivation of vegetative cells of microalga Haematococcus pluvialis. J. Biotechnol. 2009, 142, 227-232. [CrossRef]

25. Nwoba, E.G.; Parlevliet, D.A.; Laird, D.W.; Alameh, K.; Moheimani, N.R. Light management technologies for increasing algal photobioreactor efficiency. Algal Res. 2019, 39, 101433. [CrossRef]

26. Nwoba, E.G.; Parlevliet, D.A.; Laird, D.W.; Alameh, K.; Moheimani, N.R. Pilot-scale self-cooling microalgal closed photobioreactor for biomass production and electricity generation. Algal Res. 2020, 45, 101731. [CrossRef]

27. Milledge, J.J.; Heaven, S. Energy Balance of Biogas Production from Microalgae: Effect of Harvesting Method, Multiple Raceways, Scale of Plant and Combined Heat and Power Generation. J. Mar. Sci. Eng. 2017, 5, 9. [CrossRef]

28. Ferreira, A.F.; Ribeiro, L.A.; Batista, A.P.; Marques, P.; Nobre, B.P.; Palavra, A.; Silva, P.; Gouveia, L.; Silva, C. A biorefinery from Nannochloropsis sp. microalga-Energy and $\mathrm{CO}_{2}$ emission and economic analyses. Bioresour. Technol. 2013, 138, 235-244. [CrossRef]

29. Tan, X.; Lam, M.K.; Uemura, Y.; Lim, J.W.; Wong, C.Y.; Lee, K.T. Cultivation of microalgae for biodiesel production: A review on upstream and downstream processing. Chin. J. Chem. Eng. 2018, 26, 17-30. [CrossRef]

30. Faried, M.; Samer, M.; Abdelsalam, E.M.; Yousef, R.; Attia, Y.; Ali, A.S. Biodiesel production from microalgae: Processes, technologies and recent advancements. Renew. Sustain. Energy Rev. 2017, 79, 893-913. [CrossRef]

31. Chiaramonti, D.; Prussi, M.; Casini, D.; Tredici, M.R.; Rodolfi, L.; Bassi, N.; Zittelli, G.C.; Bondioli, P. Review of energy balance in raceway ponds for microalgae cultivation: Re-thinking a traditional system is possible. Appl. Energy 2013, 102, $101-111$. [CrossRef]

32. Senior, J.; Saenger, N.; Müller, G. New hydropower converters for very low-head differences. J. Hydraul. Res. 2010, 48, 703-714. [CrossRef]

33. Razon, L.F.; Tan, R.R. Net energy analysis of the production of biodiesel and biogas from the microalgae: Haematococcus pluvialis and Nannochloropsis. Appl. Energy 2011, 88, 3507-3514. [CrossRef]

34. Chang, D.K.; Jin, Y.A.; Tai, H.P.; Sang, J.S. Astaxanthin biosynthesis from simultaneous $\mathrm{N}$ and P uptake by the green alga Haematococcus pluvialis in primary-treated wastewater. Biochem. Eng. J. 2006, 31, 234-238.

35. Gupta, P.L.; Lee, S.M.; Choi, H.J. A mini review: Photobioreactors for large scale algal cultivation. World J. Microbiol. Biotechnol. 2015, 31, 1409-1417. [CrossRef]

36. Ting, H.; Lu, H.; Ma, S.; Zhang, Y.; Na, D. Progress in microalgae cultivation photobioreactors and applications in wastewater treatment: A review. Int. J. Agric. Biol. Eng. 2017, 10, 1-29.

37. Bei, W.; Lan, C.Q.; Horsman, M. Closed photobioreactors for production of microalgal biomasses. Biotechnol. Adv. 2012, 30, 904-912.

38. Hai, T.; Ahlers, H.; Gorenflo, V.; Steinbüchel, A. Axenic cultivation of anoxygenic phototrophic bacteria, cyanobacteria, and microalgae in a new closed tubular glass photobioreactor. Appl. Microbiol. Biotechnol. 2000, 53, 383-389. [CrossRef] [PubMed]

39. Dasan, Y.K.; Lam, M.K.; Yusup, S.; Lim, J.W.; Lee, K.T. Life cycle evaluation of microalgae biofuels production: Effect of cultivation system on energy, carbon emission and cost balance analysis. Sci. Total Environ. 2019, 688, 112-128. [CrossRef] [PubMed]

40. Huang, J.; Feng, F.; Wan, M.; Ying, J.; Li, Y.; Qu, X.; Pan, R.; Shen, G.; Li, W. Improving performance of flat-plate photobioreactors by installation of novel internal mixers optimized with computational fluid dynamics. Bioresour. Technol. 2015, 182, 151-159. [CrossRef]

41. Brentner, L.B.; Eckelman, M.J.; Zimmerman, J.B. Combinatorial Life Cycle Assessment to Inform Process Design of Industrial Production of Algal Biodiesel. Environ. Sci. Technol. 2011, 45, 7060-7067. [CrossRef]

42. Ozkan, A.; Kinney, K.; Katz, L.; Berberoglu, H. Reduction of water and energy requirement of algae cultivation using an algae biofilm photobioreactor. Bioresour. Technol. 2012, 114, 542-548. [CrossRef]

43. Mirón, A.; García, M.; Camacho, F.G.; Grima, E.M.; Chisti, Y. Growth and biochemical characterization of microalgal biomass produced in bubble column and airlift photobioreactors: Studies in fed-batch culture. Enzym. Microb. Technol. 2002, 31, 1015-1023. [CrossRef]

44. Huang, J.; Ying, J.; Fan, F.; Yang, Q.; Wang, J.; Li, Y. Development of a novel multi-column airlift photobioreactor with easy scalability by means of computational fluid dynamics simulations and experiments. Bioresour. Technol. 2016, 222, 399-407. [CrossRef] [PubMed]

45. Soman, A.; Shastri, Y. Optimization of novel photobioreactor design using computational fluid dynamics. Appl. Energy 2015, 140, 246-255. [CrossRef]

46. Branco-Vieira, M.; Costa, D.B.; Mata, T.M.; Martins, A.A.; Caetano, N.S. Environmental assessment of industrial production of microalgal biodiesel in Central-south Chile. J. Clean. Prod. 2020, 266, 121756. [CrossRef] 
47. Chen, C.Y.; Chang, J.S.; Chang, H.Y.; Chen, T.Y.; Wu, J.H.; Lee, W.L. Enhancing microalgal oil/lipid production from Chlorella sorokiniana CY1 using deep-sea water supplemented cultivation medium. Biochem. Eng. J. 2013, 77, 74-81. [CrossRef]

48. Abomohra, A.E.-F.; El-Sheekh, M.; Hanelt, D. Pilot cultivation of the chlorophyte microalga Scenedesmus obliquus as a promising feedstock for biofuel. Biomass Bioenergy 2014, 64, 237-244. [CrossRef]

49. Kim, Z.H.; Park, H.; Hong, S.J.; Lim, S.M.; Lee, C.G. Development of a floating photobioreactor with internal partitions for efficient utilization of ocean wave into improved mass transfer and algal culture mixing. Bioprocess Biosyst. Eng. 2016, 39, 713-723. [CrossRef]

50. Tredici, M.R.; Bassi, N.; Prussi, M.; Biondi, N.; Rodolfi, L.; Zittelli, G.C.; Sampietro, G. Energy balance of algal biomass production in a 1-ha "Green Wall Panel" plant: How to produce algal biomass in a closed reactor achieving a high Net Energy Ratio. Appl. Energy 2015, 154, 1103-1111. [CrossRef]

51. Lam, T.P.; Lee, T.M.; Chen, C.-Y.; Chang, J.-S. Strategies to control biological contaminants during microalgal cultivation in open ponds. Bioresour. Technol. 2018, 252, 180-187. [CrossRef]

52. Adesanya, V.O.; Cadena, E.; Scott, S.A.; Smith, A.G. Life cycle assessment on microalgal biodiesel production using a hybrid cultivation system. Bioresour. Technol. 2014, 163, 343-355. [CrossRef] [PubMed]

53. Brennan, L.; Owende, P. Biofuels from microalgae-A review of technologies for production, processing, and extractions of biofuels and co-products. Renew. Sustain. Energy Rev. 2010, 14, 557-577. [CrossRef]

54. Beal, C.M.; Gerber, L.N.; Sills, D.L.; Huntley, M.E.; Machesky, S.C.; Walsh, M.J.; Tester, J.W.; Archibald, I.; Granados, J.; Greene, C.H. Algal biofuel production for fuels and feed in a 100-ha facility: A comprehensive techno-economic analysis and life cycle assessment. Algal Res. 2015, 10, 266-279. [CrossRef]

55. Kunjapur, A.M.; Eldridge, R.B. Photobioreactor design for commercial biofuel production from microalgae. Ind. Eng. Chem. Res. 2010, 49, 3516-3526. [CrossRef]

56. Aliyu, A.; Lee, J.; Harvey, A.P. Microalgae for biofuels via thermochemical conversion processes: A review of cultivation, harvesting and drying processes, and the associated opportunities for integrated production. Bioresour. Technol. Rep. 2021, 14, 100676. [CrossRef]

57. Christenson, L.; Sims, R. Production and harvesting of microalgae for wastewater treatment, biofuels, and bioproducts. Biotechnol. Adv. 2011, 29, 686-702. [CrossRef] [PubMed]

58. Schiel, D.R.; Gunn, T.D. Effects of sediment on early life history stages of habitat-dominating fucoid algae. J. Exp. Mar. Biol. Ecol. 2019, 516, 44-50. [CrossRef]

59. Garzon-Sanabria, A.J.; Davis, R.T.; Nikolov, Z.L. Harvesting Nannochloris oculata by inorganic electrolyte flocculation: Effect of initial cell density, ionic strength, coagulant dosage, and media pH. Bioresour. Technol. 2012, 118, 418-424. [CrossRef]

60. Pragya, N.; Pandey, K.K.; Sahoo, P.K. A review on harvesting, oil extraction and biofuels production technologies from microalgae. Renew. Sustain. Energy Rev. 2013, 24, 159-171. [CrossRef]

61. Bhave, R.; Kuritz, T.; Powell, L.; Adcock, D. Membrane-Based Energy Efficient Dewatering of Microalgae in Biofuels Production and Recovery of Value Added Co-Products. Environ. Sci. Technol. 2012, 46, 5599-5606. [CrossRef]

62. Da Nquah, M.K.; Li, A.; Uduman, N.; Moheimani, N.; Forde, G.M. Dewatering of microalgal culture for biodiesel production: Exploring polymer flocculation and tangential flow filtration. J. Chem. Technol. Biotechnol. 2009, 84, 1078-1083. [CrossRef]

63. Roy, M.; Mohanty, K. A comprehensive review on microalgal harvesting strategies: Current status and future prospects. Algal Res. 2019, 44, 101683. [CrossRef]

64. Verma, N.M.; Mehrotra, S.; Shukla, A.; Mishra, B.N. Prospective of biodiesel production utilizing microalgae as the cell factories: A comprehensive discussion. Afr. J. Biotechnol. 2010, 9, 1402-1411.

65. Thomassen, G.; Vila, U.E.; Dael, M.V.; Lemmens, B.; Passel, S.V. A techno-economic assessment of an algal-based biorefinery. Clean Technol. Environ. Policy 2016, 18, 1-14. [CrossRef]

66. Xin, C.; Addy, M.M.; Zhao, J.; Cheng, Y.; Cheng, S.; Mu, D.; Liu, Y.; Ding, R.; Chen, P.; Ruan, R. Comprehensive techno-economic analysis of wastewater-based algal biofuel production: A case study. Bioresour. Technol. 2016, 211, 584-593. [CrossRef] [PubMed]

67. Zhang, H.; Zhang, X. Microalgal harvesting using foam flotation: A critical review. Biomass Bioenergy 2019, 120, 176-188. [CrossRef]

68. Huang, Z.; Cheng, C.; Li, L.; Guo, Z.; He, G.; Yu, X.; Liu, R.; Han, H.; Deng, L.; Fu, W. Morpholine-Based Gemini Surfactant: Synthesis and Its Application for Reverse Froth Flotation of Carnallite Ore in Potassium Fertilizer Production. J. Agric. Food Chem. 2018, 66, 13126-13132. [CrossRef]

69. Chen, C.Y.; Yeh, K.L.; Aisyah, R.; Lee, D.J.; Chang, J.S. Cultivation, photobioreactor design and harvesting of microalgae for biodiesel production: A critical review. Bioresour. Technol. 2011, 102, 71-81. [CrossRef] [PubMed]

70. Pugazhendhi, A.; Shobana, S.; Bakonyi, P.; Nemestóthy, N.; Xia, A.; Banu, J.R.; Kumar, G. A review on chemical mechanism of microalgae flocculation via polymers. Biotechnol. Rep. 2019, 21, e00302. [CrossRef]

71. Lei, X.; Zheng, W.; Ding, H.; Zhu, X.; Chen, Q.; Xu, H.; Zheng, T.; Tian, Y. Effective harvesting of the marine microalga Thalassiosira pseudonana by Marinobacter sp. FL06. Bioresour. Technol. 2018, 269, 127-133. [CrossRef]

72. Lv, J.; Guo, B.; Feng, J.; Liu, Q.; Nan, F.; Liu, X.; Xie, S. Integration of wastewater treatment and flocculation for harvesting biomass for lipid production by a newly isolated self-flocculating microalga Scenedesmus rubescens SX. J. Clean. Prod. 2019, $240,118211$. [CrossRef] 
73. Suparmaniam, U.; Lam, M.K.; Uemura, Y.; Lim, J.W.; Lee, K.T.; Shuit, S.H. Insights into the microalgae cultivation technology and harvesting process for biofuel production: A review. Renew. Sustain. Energy Rev. 2019, 115, 109361. [CrossRef]

74. Thangavel, M.; Nirupama, M. A comprehensive review on harvesting of microalgae for biodiesel-Key challenges and future directions. Renew. Sustain. Energy Rev. 2018, 91, 1103-1120.

75. Show, K.Y.; Lee, D.J.; Chang, J.S. Algal biomass dehydration. Bioresour. Technol. 2013, 135, 720-729. [CrossRef]

76. Liao, Y.; Huang, Z.; Ma, X. Energy analysis and environmental impacts of microalgal biodiesel in China. Energy Policy 2012, 45, 142-151.

77. Aziz, M.; Oda, T.; Kashiwagi, T. Integration of energy-efficient drying in microalgae utilization based on enhanced process integration-ScienceDirect. Energy 2014, 70, 307-316. [CrossRef]

78. Passell, H.; Dhaliwal, H.; Reno, M.; Ben, W.; Amotz, A.B.; Ivry, E.; Gay, M.; Czartoski, T.; Laurin, L.; Ayer, N. Algae biodiesel life cycle assessment using current commercial data. J. Environ. Manag. 2013, 129, 103-111. [CrossRef]

79. Sagar, V.R.; Kumar, P.S. Recent advances in drying and dehydration of fruits and vegetables: A review. J. Food Sci. Technol. 2010, 47, 15-26. [CrossRef] [PubMed]

80. Ratti, C.J. Hot air and freeze-drying of high-value foods: A review. J. Food Eng. 2001, 49, 311-319. [CrossRef]

81. Posten, C. Design principles of photo-bioreactors for cultivation of microalgae. Eng. Life Sci. 2010, 9, 165-177. [CrossRef]

82. Huang, Q.; Jiang, F.; Wang, L.; Yang, C. Design of Photobioreactors for Mass Cultivation of Photosynthetic Organisms. Engineering 2017, 3, 318-329. [CrossRef]

83. Hu, Q.; Kurano, N.; Kawachi, M.; Iwasaki, I.; Miyachi, S. Ultrahigh-cell-density culture of a marine green alga Chlorococcum littorale in a flat-plate photobioreactor. Appl. Microbiol. Biotechnol. 1998, 49, 655-662. [CrossRef]

84. Ugwu, C.; Aoyagi, H.; Uchiyama, H. Photobioreactors for mass cultivation of algae. Bioresour. Technol. 2008, 99, 4021-4028. [CrossRef] [PubMed]

85. Jonker, J.; Faaij, A. Techno-economic assessment of micro-algae as feedstock for renewable bio-energy production. Appl. Energy 2013, 102, 461-475. [CrossRef]

86. Raghuvanshi, S.; Bhakar, V.; Chava, R.; Sangwan, K.S. Comparative Study Using Life Cycle Approach for the Biodiesel Production from Microalgae Grown in Wastewater and Fresh Water. Procedia CIRP 2018, 69, 568-572. [CrossRef]

87. Pankratz, S.; Kumar, M.; Oyedun, A.O.; Gemechu, E.; Kumar, A. Environmental performances of diluents and hydrogen production pathways from microalgae in cold climates: Open raceway ponds and photobioreactors coupled with thermochemical conversion. Algal Res. 2020, 47, 101815. [CrossRef]

88. Beal, C.M.; Hebner, R.E.; Webber, M.E.; Ruoff, R.S.; Seibert, A.F. The Energy Return on Investment for Algal Biocrude: Results for a Research Production Facility. BioEnergy Res. 2011, 5, 341-362. [CrossRef]

89. Gupta, A.K.; Hall, C.A. A Review of the Past and Current State of EROI Data. Sustainability 2011, 3, 1796-1809. [CrossRef]

90. Medeiros, D.L.; Sales, E.; Kiperstok, A. Energy production from microalgae biomass: Carbon footprint and energy balance. J. Clean. Prod. 2015, 96, 493-500. [CrossRef]

91. Chowdhury, R.; Franchetti, M. Life cycle energy demand from algal biofuel generated from nutrients present in the dairy waste. Sustain. Prod. Consum. 2017, 9, 22-27. [CrossRef]

92. Bva, B.; Dc, C.; Tmm, A.; Aam, A.; Mavf, B.; Nsca, D. A life cycle inventory of microalgae-based biofuels production in an industrial plant concept. Energy Rep. 2020, 6, 397-402.

93. Banu, J.R.; Preethi; Kavitha, S.; Gunasekaran, M.; Kumar, G. Microalgae based biorefinery promoting circular bioeconomy-techno economic and life-cycle analysis. Bioresour. Technol. 2020, 302, 122822. [CrossRef] [PubMed]

94. Assuno, J.; Malcata, F.X. Enclosed "non-conventional" photobioreactors for microalga production: A review. Algal Res. 2020, 52, 102-107.

95. Qiang, H.; Faiman, D.; Richmond, A. Optimal tilt angles of enclosed reactors for growing photoautotrophic microorganisms outdoors. J. Ferment. Bioeng. 1998, 85, 230-236. [CrossRef]

96. Vicente, G.; Bautista, L.F.; Gutiérrez, F.J.; Rodríguez, R.; Martínez, V.; Rodríguez-Frómeta, R.A.; Ruiz-Vázquez, R.M.; TorresMartínez, S.; Garre, V. Direct Transformation of Fungal Biomass from Submerged Cultures into Biodiesel. Energy Fuels 2010, 24, 3173-3178. [CrossRef]

97. Kita, K.; Okada, S.; Sekino, H.; Imou, K.; Yokoyama, S.; Amano, T. Thermal pre-treatment of wet microalgae harvest for efficient hydrocarbon recovery. Appl. Energy 2010, 87, 2420-2423. [CrossRef]

98. Ap, A.; Sn, B.; Rrb, C.; Pct, D.; Sn, B.; Sd, E.; Ah, F.; Vkpd, G.; Gk, H. Various potential techniques to reduce the water footprint of microalgal biomass production for biofuel-A review. Sci. Total Environ. 2020, 749, 142218.

99. Nwoba, E.G.; Parlevliet, D.A.; Laird, D.W.; Alameh, K.; Louveau, J.; Pruvost, J.; Moheimani, N. Energy efficiency analysis of outdoor standalone photovoltaic-powered photobioreactors coproducing lipid-rich algal biomass and electricity. Appl. Energy 2020, 275, 115403. [CrossRef]

100. Hulatt, C.J.; Thomas, D. Productivity, carbon dioxide uptake and net energy return of microalgal bubble column photobioreactors. Bioresour. Technol. 2011, 102, 5775-5787. [CrossRef]

101. Morales, M.; Hélias, A.; Bernard, O. Optimal integration of microalgae production with photovoltaic panels: Environmental impacts and energy balance. Biotechnol. Biofuels 2019, 12, 1-17. [CrossRef] 